\title{
EL ARZOBISPADO DE COMPOSTELA, LOS OBISPADOS DEL NOROESTE DE LA PENÍNSULA IBÉRICA Y EL IV CONCILIO DE LETRÁN DE 1215
}

\author{
POR \\ SANTIAGO DOMÍNGUEZ SÁNCHEZ ${ }^{1}$ \\ Universidad de León
}

\begin{abstract}
RESUMEN
En este artículo se estudia y analiza críticamente la participación de los obispos del noroeste de la península ibérica en el IV Concilio de Letrán del año 1215, cuyo octavo centenario se celebra ahora. Se hace un pequeño repaso a la aplicación paulatina en este territorio de seis decisiones conciliares: la primera, el problema de la primacía de la Iglesia hispana, especialmente con las luchas entre los arzobispos de Toledo y Compostela, así como la imposición de un mayor control en la disciplina eclesiástica, las diversas disposiciones para la mejora de la vida de piedad de los fieles, una nueva regulación del sacramento del matrimonio, las medidas tomadas en relación con los judíos y el llamamiento a la cruzada.
\end{abstract}

PALABRAS CLAVE: IV Concilio de Letrán; siglo XIII (primera mitad); arzobispado de Compostela y obispados del noroeste de la península ibérica; disposiciones conciliares.

\section{THE ARCHBISHOP OF COMPOSTELA, THE BISHOPS OF THE NORTHWEST SPAIN AND THE FOURTH LATERAN COUNCIL (1215)}

\begin{abstract}
This paper critically examines and analyzes the participation of the bishops of the Northwest Spain in the Fourth Lateran Council of 1215, whose eighth centenary is now celebrated. The article details the gradual implementation in this territory of six council provisions: first, the question of the primacy of the Hispanic Church, especially with the struggles between the archbishops of Toledo and Compostela, and also, the imposition of greater control in ecclesiastical discipline, the various requirements for improving a stronger piety of the faithful, a new regulation of the sacrament of marriage, certain measures taken in relation to the Jews and, finally, the call and appeal for the Crusade.
\end{abstract}

KEY WORDS: Fourth Lateran Council; Thirteenth Century (first half); Archbishop of Compostela and bishops of the Northwest Spain; Conciliary provisions.

COMO CITAR ESTE ARTículo / CITATION: Domínguez Sánchez S. 2017. «El arzobispado de Compostela,los obispados del noroeste de la península ibérica y el IV Concilio de Letrán de 1215». Hispania Sacra 69, 140: 487-503. doi: 10.3989/hs.2017.030

Recibido/Received 28-01-2016

Aceptado/Accepted 01-10-2016

En noviembre del año 1215, hace ahora exactamente 800 años, se inauguró en Letrán uno de los más importantes Concilios de la historia de la Cristiandad, tanto por el número y condición de los asistentes, como por las decisiones tomadas en el mismo, como también por las consecuencias posteriores de tales disposiciones conciliares.

Entre los más de 400 obispos asistentes al Concilio IV Ecuménico de Letrán se encontraban numerosos prelados pertenecientes a la provincia eclesiástica de Compostela

\footnotetext{
${ }^{1}$ sdoms@unileon.es / ORCID iD: http://orcid.org/0000-0002
} $-5099-6307$ y, en conjunto, al noroeste de la península ibérica. Ello era consecuencia del llamamiento que casi dos años antes, el 19 de abril de 1213, había hecho Inocencio III a los arzobispos, obispos, abades y priores de las provincias eclesiásticas de Tarragona, Toledo, Braga y Compostela para que acudiesen a dicho Concilio. ${ }^{2}$

Como decía anteriormente, las disposiciones aprobadas en este Concilio, aunque no fueron de aplicación inmediata

2 Ed. por Mansilla Reoyo 1955: 543-555, doc. 503. También fueron convocados con la misma fecha los reyes de Aragón, Navarra, Castilla, León y Portugal. 
ni fácil en la península ibérica ${ }^{3}$, acabaron siendo de gran calado, especialmente en seis aspectos: la primacía en la Iglesia hispana, la disciplina eclesiástica y el control de la vida capitular y monástica, el intento de mejorar la vida de piedad de los fieles, la regulación del sacramento del matrimonio, las medidas tomadas con relación a los judíos o la convocatoria general a la Quinta Cruzada. ${ }^{4}$

Tales medidas conciliares ${ }^{5}$, como es evidente, tardaron en ponerse en marcha, más aún en el noroeste de la península ibérica, que por entonces era considerada una región lejana y de difícil acceso. Por ello los pontífices romanos, en los años siguientes, enviaron a esta zona sus legados, tratando de que dichas disposiciones tuvieran efecto rápidamente y de forma duradera. Entre ellos hay que destacar la labor del afamado cardenal Jean Halgrin de Abbeville, que, con su venida a España en 1228, despertó la aletargada actitud de la Iglesia ibérica e impulsó en gran medida la aceptación de los decretos conciliares. Varios concilios hispanos de la decimotercera centuria ${ }^{6}$ "citan expresamente las constituciones del Concilio IV de Lateranense, dejando entrever su incumplimiento y urgiendo que se lleven a la práctica». ${ }^{7}$

Puesto que se va a tratar de la participación de los prelados del noroeste hispano en dicho Concilio, parece conveniente dedicar unas breves palabras a describir la complicada organización de la Iglesia en esta región hispana. ${ }^{8}$

Como es sabido, el famoso prelado Diego Gelmírez consiguió ${ }^{9}$ cien años antes de la celebración de este Concilio, exactamente en 1120, que el papa estableciese la provincia eclesiástica compostelana. ${ }^{10}$ La sede diocesana de Compostela tiene su origen en la cercana sede de Iria, cuyo nacimiento se remonta a la época de los suevos, aproximadamente al año 561. Tras el descubrimiento del sepulcro del apóstol Santiago y el auge de las peregrinaciones, dicha sede de Iria se trasladó a Compostela, lo cual tuvo lugar definitivamente en el año $1095^{11}$, momento en el que consiguió también la exención del metropolitano bracarense. Nueve años más tarde, en $1104^{12}$, Diego Gelmírez logró la dignidad metropolitana, aunque sin tener diócesis sufragáneas. ${ }^{13}$ Parece que Gelmírez pretendía arrebatar a Braga la dignidad metro-

3 Cf. Linehan 1975: 4 ss.

4 Cf. Entre otras, las obras clásicas de Mansi 1778: cols. 9531082 (donde se editan las actas del concilio); Luchaire 1908; Hefele, y Leclercq, 1913: 1316-1398; García y García 1958-1959 y 1972; Alberigo 1962; Gibbs y Lang 1962; Lomax 1969; Azais, Thouzellier y Fliche 1975.

5 En la península ibérica, al contrario de lo que pasa en otras regiones europeas, sólo hay un códice que copie de forma manuscrita las constituciones de este Concilio Lateranense: el ms. 15-26 de la Biblioteca Capitular Toledana. Véase la edición crítica de tales constituciones en García y García 1981.

6 Sobre la puesta en práctica de las decisiones pontificias en los lugares periféricos de la Cristiandad, cf. Schieffer 2013. Véase también Martín Martín 2011. Sobre la recepción de las normas canónicas pontificias en el oeste hispano, cf. Fleisch 2011.

7 García y García 1972.

8 Cf. Domínguez Sánchez y Herbers (coords.) 2009.

9 Cf. El excelente trabajo de Mansilla Reoyo 1972. Estos datos los amplió el autor más tarde en: Mansilla Reoyo 1994: 15-67 y 261-272.

10 Cf. Falque Rey 1994.

11 Cf. Jaffé 1851.

12 Cf. Jaffé 1885-1888: núm. 5986.

13 Como es sabido, por desgracia no se conserva ningún documento pontificio original anterior al año 1198 y dirigido a la sede compostelana. Sobre este problema, cf. López Alsina 2011. politana ${ }^{14}$, pero, ante la negativa de Calixto II a aceptar este cambio, el sagaz prelado compostelano consiguió que el pontificado le adjudicara el rango metropolitano que había tenido Mérida en la antigua Lusitania, que todavía estaba ocupada por los musulmanes. ${ }^{15}$ Calixto II hizo una primera concesión transitoria de dicha dignidad metropolitana en $1120^{16}, y$, cuatro años después, en $1124,{ }^{17}$ dicha concesión se hizo definitiva. ${ }^{18}$

En un principio Calixto II asignó como sufragáneas de Compostela las sedes de Ávila, Salamanca y Coímbra, que eran las que por entonces estaban restauradas. Anastasio IV, en 1154, añade las diócesis de Coria y Lisboa, que acababan de restaurarse, y reconoce a Compostela el derecho sobre las demás sedes que antiguamente habían pertenecido a Mérida. ${ }^{19}$ Alejandro III, en 1178, le añade las diócesis de Ciudad Rodrigo y Évora, y las sedes no restauradas de Badajoz y Faro. ${ }^{20}$ A principios del siglo XIII Compostela logró, además, incorporar a su provincia los obispados de Zamora $^{21}$, Plasencia, Lamego e Idanha-Guarda.

Así se llega al año 1215. En el momento de la celebración del IV Concilio de Letrán la capitalidad de esta provincia compostelana lógicamente estaba en la ciudad de Santiago de Compostela, y dicha mitra arzobispal reunía las siguientes sedes episcopales: Salamanca, Zamora, Ávila, Ciudad Rodrigo, Plasencia, Coria, Lisboa, Évora, Lamego e Idanha-Guarda. Como se ve, ninguna sede estaba en la región de Galicia, en la que se encuentra Compostela. ${ }^{22}$ Las diócesis del arzobispado compostelano se encontraban en el sur del Reino de León (Zamora, Salamanca, Ciudad Rodrigo y Coria), en Castilla (Ávila y Plasencia), o en Portugal (Lisboa, Évora, Lamego e Idanha-Guarda).

Por su parte, el noroeste hispano, en este momento, se encuadraba dentro del Reino de León, que estaba gobernado por su último rey, Alfonso IX, hasta poco después, exactamente hasta 1230 . Los obispados de dicho reino eran los siguientes: la sede arzobispal de Compostela, y las episcopales de Mondoñedo, Lugo, Orense, Tui, Astorga, Oviedo, León, Zamora, Salamanca, Ciudad Rodrigo y Coria.

14 Según informa la Historia Compostelana, libro II, cap. III. Cf. la edición clásica de Flórez 1765: 255-259.

15 Hasta el año 1230, siendo, con Badajoz, la última de las grandes ciudades ocupadas por Alfonso IX de León.

16 Cf. Jaffé 1885-1888: núm. 6823. No debe olvidarse que Calixto II era hermano de Raimundo de Borgoña, y, por tanto, tío del emperador Alfonso VII, lo que ayudó a que las relaciones con Gelmírez fueran fluidas. Cf. González Vázquez 1996: 113ss. (aunque esta autora confunde Calixto II con Pascual II).

17 Cf. Jaffé 1885-1888: núm. 7160.

18 Desde este momento progresivamente aumentan y se afianzan las propiedades de la mitra compostelana. Cf. González Vázquez 1996, esp. 34-72.

19 Cf. López Ferreiro 1898-1911: IV, Apénd., 60-64, núm. 22, 11 vols.

20 Cf. ibídem: Apénd., 126-134, núm. 52.

21 Que hasta 1153 había dependido de facto del arzobispo de Toledo y luego del metropolitano de Braga.

22 Los obispados gallegos continuaron varios siglos perteneciendo a la provincia de Braga, hasta que en el año 1393 Bonifacio IX, papa en Roma, creó la metrópoli de Lisboa, con las sufragáneas de Évora, Lamego e Idanha, que hasta entonces habían pertenecido a Compostela, y con Silves, que pertenecía a Sevilla. Por su lado, al año siguiente, en 1394, Clemente VII, papa en Aviñón, ordenó que todos los obispados gallegos (Mondoñedo, Lugo, Orense y Tui) y el de Astorga, hasta entonces dependientes de Braga, pasaran a depender de Compostela. Solucionado el Cisma de Occidente con Martín V en 1417, estas citadas decisiones de sus predecesores se respetaron. 
Pues bien, ¿qué prelados del noroeste hispano participaron en este referido IV Concilio de Letrán? El elenco de los más de veinte obispos ibéricos presentes en el mismo, aunque discutido y variable según las fuentes, es conocido desde hace tiempo. Sabemos de él por vías diversas, a la vez que complementarias, centradas en diversos manuscritos más o menos coetáneos:

En primer lugar, el ms. Car. c. 148 de la Zentralbibliothek de Zurich, en sus folios $46 \mathrm{v}-48 \mathrm{v}$, contiene el listado más completo de los obispos hispanos asistentes al Concilio ${ }^{23}$, y de otros 46 personajes delegados de los cabildos o acompañantes de los citados ordinarios. Dicho elenco, descubierto a principios del siglo xx por el profesor Werner, fue publicado por el profesor Luchaire poco después. ${ }^{24}$

Por lo que afecta al noroeste hispano, según dicho manuscrito, participaron en dicho Concilio los siguientes prelados:

- por la provincia eclesiástica de Compostela: el arzobispo de Compostela (Pedro Muñiz), los obispos leoneses de Salamanca (Gonzalo Fernández) y Ciudad Rodrigo (Lombardo), más los obispos portugueses de Guarda (Martinho Paes) y Lisboa (Soeiro Viegas). Además, también estuvo presente el obispo castellano de Ávila (Domingo Blasco). ${ }^{25}$

- por la provincia eclesiástica de Braga: el arzobispo de Braga (Estêvão Soares da Silva), los obispos leoneses de Astorga (Pedro Andrés), Mondoñedo (Pelayo de Cebeira) y Orense (Fernando Méndez), más los obispos portugueses de Coímbra (Pedro Soeiro) y Oporto (Julião). ${ }^{26}$

- por lo que respecta a sedes episcopales exentas, pertenecientes al Reino de León: los prelados de Oviedo (Juan) y León (Rodrigo Álvarez).

En segundo lugar, el académico Fidel Fita, también a principios de siglo $\mathrm{Xx}^{27}, \mathrm{y}$ de nuevo el historiador y archivero de Toledo Rivera Recio, a mediados de esta centuria ${ }^{28}$, publicaron un interesante texto inserto en el ms. 42-21 de la Biblioteca Capitular de Toledo. Tal códice, de la segunda mitad del siglo XIII, titulado De privilegiis et primatu ecclesiae Toletanae, copia numerosos diplomas papales relacionados con la primacía eclesiástica de Toledo, desde Urbano II hasta Honorio III, esto es, de 1088 a 1227. En un folio originariamente independiente y más tarde inserto en dicho manuscrito se transcribe cierto proceso judicial, del propio año 1215 , surgido con motivo de la controvertida primacía toledana. En su parte final el documento informa de "His autem omnibus interfuerunt testes de Yspania, qui ea audierunt et viderunt...»

23 «Nomina cardinalium, patriarcarum, archiepiscoporum, episcoporum qui interfuerunt Universali Concilio Ionnocentii Papae.»: concretamente, los de Oviedo, Burgos, León, Toledo, Cuenca, Segovia, Osma, Segorbe, Compostela, Salamanca, Guarda, Lisboa, Ciudad Rodrigo, Ávila, Tarragona, Gerona, Barcelona, Vic, Urgell, Calahorra, Braga, Astorga, Mondoñedo, Orense, Coímbra, Oporto (y Narbona). Por tanto, sólo dejaron de asistir a Concilio 16 obispos hispanos.

24 Cf. Luchaire 1905.

25 No asistieron los obispos de Zamora, Coria, Plasencia, Lamego y Évora.

26 En consecuencia, excusaron su presencia los prelados de Lugo, Tui y Viseu.

27 Fita Colomé 1902.

28 Rivera Recio 1951. Véase también García y García 1987: 204-208.
Entre ellos, por lo que se refiere al noroeste hispano, aparecen en este manuscrito toledano sólo 17 obispos hispanos participantes, concretamente los que estuvieron presentes en la discusión (preliminar al Concilio ${ }^{29}$ ) sobre el primado de la Iglesia hispana. Los prelados de la zona noroeste de la península ibérica que aparecen en este manuscrito son los siguientes: Episcopi Colimbriensis (Pedro Soeiro); Ulixbonensis (Soeiro Viegas); Portugalensis (Julião); Egitaniensis (Martinho Paes); Civitatensis (Lombardo); Asturicensis (Pedro Andrés); Auriensis (Fernando Méndez); Ovetensis (Juan). ${ }^{30}$

En fin, conocidos los participantes en el Concilio IV de Letrán, corresponde ahora prestar atención a los diversos asuntos tocados en el mismo, algunos de los cuales ya aparecen reseñados en la ya citada «bula» de convocatoria del Concilio de abril de $1213^{31}$, que textualmente dice lo siguiente:

(...) Generale Concilium iuxta priscam Sanctorum Patrum consuetudinem convocemus, propter lucra solummodo animarum opportuno tempore celebrandum, in quo ad extirpanda vitia et plantandas virtutes, corrigendos excessus et reformandos mores, eliminandas hereses et roborandam fidem, sopiendas discordias et stabiliendam pacem, comprimendas oppressiones et libertatem fovendam, inducendos principes et populos christianos ad succursum et subsidium Terre Sancte, tam a clericis quam a laicis impendendum cum ceteris, que longum esset per singula numerare; provide statuantur inviolabiliter observanda circa prelatos et subditos regulares et seculares, quecumque de ipsius approbatione Concilii visa fuerint expedire, ad laudem et gloriam nominis Eius, remedium et salutem animarum vestrarum et profectum et utilitatem populi christiani (...)

Es importante comentar ahora los seis aspectos antes señalados en los que tuvieron especial relevancia las decisiones conciliares, y cuya relación con el noroeste hispano es relevante:

\section{PRIMACÍA EN LA IGLESIA HISPANA}

A pesar de que en los últimos años ha habido varios y muy buenos estudios sobre este tema ${ }^{32}$, ofrecemos ahora una sencilla exposición y análisis de unos hechos conocidos, comenzando por exponer el origen y desarrollo histórico del problema, a fin de poder comprenderlo con más claridad.

Los defensores de la primacía (sea toledana, lugdunense, de Canterbury, etc.) han puesto de manifiesto ${ }^{33}$ que desde la época del Concilio de Calcedonia del año 451, por razones de orden histórico-político, se concedió a algunas iglesias el título de "primadas», de un modo distinto, pero en cierta manera aproximado al rango de "patriarcales» que

29 De hecho, sabemos que algunos obispos se presentaron en el Concilio días más tarde. Dice este manuscrito: «Narbonensis vero non erat presens illa die, sed alia die respondit in Consistorio».

${ }_{30}$ Y, además, "Petrus Salvatoris et Melendus Gonsalvi, canonici Portugalenses».

31 Cf. Mansilla Reoyo 1955: 543-545, núm. 503.

32 Véanse, entre otros, los trabajos de Horn 1991 y de Henriet 2004, en I. Alfonso Antón, H. N. Kennedy y J. Escalona Monge (eds.) 2: 291-318.

33 En diversas obras aparecidas ya desde el siglo XVI. 
ostentaban otras sedes como Antioquía o Alejandría. Dicho título de sede primada iba vinculado a una cierta prerrogativa de honor y precedencia por encima de los arzobispos y obispos de una región o reino, aunque normalmente ello no concedía derechos especiales de jurisdicción.

Desde el siglo Xı en adelante los defensores de la primacía toledana sobre la Iglesia hispana ${ }^{34}$ han apelado al canon 6으 del XII Concilio de Toledo, celebrado en el año 681, por el cual, por concesión de todos los metropolitanos hispanos, le correspondía al metropolitano de Toledo la facultad de elección, examen y consagración de todos los obispos de todas las metrópolis hispanas: ${ }^{35}$ así, desde entonces encabeza las suscripciones de los concilios XIII al XVIII. ${ }^{36}$ La causa de tal preponderancia de la Iglesia toledana, que no literalmente primacía, está en el hecho de que la sede toledana era la sede regia visigoda, y en la patente intervención de los reyes visigodos en las elecciones episcopales de aquel momento. Además, parece que durante la invasión musulmana el metropolitano de Toledo mantuvo una cierta preeminencia sobre los obispos de la península, tal como atestiguan textos de Beato de Liébana, Alcuino, etc.

Tras la reconquista en 1085 de la significativa ciudad toledana, antigua capital del reino visigodo, y la posterior restauración de la sede arzobispal en 1086, parecía muy probable que a dicha mitra se le concediese un especial relieve en la Iglesia ibérica, aunque con características diversas del que había tenido en época visigoda, especialmente teniendo en cuenta la reforma en las estructuras de la Iglesia liderada por Gregorio VII. ${ }^{37}$ Poco después, el 15 de octubre de 1088, Urbano II $^{38}$ estableció $^{39}$ que el arzobispo de Toledo fuese el primado de todos los obispos de la península ibérica:

Teque, sicut eiusdem urbis antiquitus constat extitisse pontifices in totis Hispaniarum regnis primatem, privilegii nostri sanctione statuimus ... Primatem te universi Hispaniarum presules respicient, et ad te, si quid inter eos questione dignum exortum fuerit, referent, salva tamen Romane auctoritate Ecclesie et metropolitanorum privilegiis singulorum.

En el diploma expedido por Urbano II queda reflejada claramente la voluntad pontificia de instaurar al metropolitano toledano como primado hispano y como árbitro o juez

34 Cf. sobre ello los trabajos de Rivera Recio 1966-1973, en Aldea Vaquero, Marín Martínez y Vives Gatell (eds.) 1973: 2024-2027. Véanse también las obras clásicas de Castejón y Fonseca 1645; Flórez 1751: 241 308 (capítulo dedicado a la primacía de Toledo).

35 Editado ya antiguamente por Loaysa y Girón 1595. Dicho canon 6o lleva por título: «De concessa Toletano pontifici generalis Synodi potestate, ut episcopi alterius provinciae, cum conniventia principum, in urbe regia ordinentur». En este canon se acuerda lo siguiente: Unde placuit omnibus pontificibus Hispaniae ut, salvo privilegio uniuscuisque provinciae, licitum maneat deinceps Toletano pontifici, quoscumque regalis potestas elegerit, et iam dicti Toletani episcopi iudicio dignos esse probaverit, in quibuslibet provinciis, in praecedentium sedibus praeficere praesules, et decedentibus episcopus eligere successores.

36 De los años 683, 684, 688, 693, 694 y ca. 702.

37 Quien, significativamente, en el año 1079, había decretado que el arzobispo de Lyon fuese el primado sobre las provincias eclesiásticas de Lyon, Rouen, Tours y Sens.

38 Cf. Jaffé 1885-1888: núm. 5366; y Mansilla Reoyo 1955: 43-45, núm. 27. Véase la traducción al castellano en Flórez 1751: 305-306.

39 Para algunos investigadores «restableció». último al que se deberá acudir ante cualquier problema grave que surja entre los obispos de la península. Todos los prelados hispanos deberían a partir de entonces prestarle reverencia y acatar su autoridad, entre ellos los arzobispos de Braga, Compostela y Tarragona. ${ }^{40}$ Además, como es bien sabido, el primer arzobispo de Toledo, Bernardo de Cluny (1086-1124), fue muy pronto designado como legado pontificio, desde el año 1093, lo cual aumentó su prestigio y fuerza entre sus colegas prelados hispanos. En la consecución de tal diploma de Urbano II se ha reconocido la mano de Alfonso VI, a cuya idea imperial de un dominio (imperium) sobre los demás reyes hispanos quería acompañar de una análoga supremacía de la Iglesia de Toledo sobre las demás Iglesias ibéricas. ${ }^{41}$ También se ha visto en este reconocimiento la hábil mano del arzobispo don Bernardo de Cluny, que supo presentar de manera interesada a Urbano II los textos antiguos relativos a la primacía toledana en tiempos antiguos.

Desde muy pronto hubo resistencias por parte de diversos arzobispos a esta primacía toledana. Los argumentos esgrimidos en contra de la misma los resume con nitidez Gorosterratzu: "Los adversarios pretendían que los derechos de primacía debían tener su origen en la prioridad de la restauración después de la invasión sarracena. Eso alegó el bracarense contra Toledo, por cuanto fue la primera metrópoli que se libró de los agarenos. Lo mismo Compostela, pero de manera más oblicua, diciendo que por Calixto II, cuando ese Papa unió Braga a Compostela por los manejos de Gelmírez, habían sido transferidos a Compostela los derechos de Braga. El narbonense en cambio se apoyaba en otro principio, a saber, que Narbona recogió todos los derechos metropolitanos de Tarragona durante la invasión árabe (...) El tarraconense siempre se creyó anterior al toledano y nunca reconoció, sobre todo en el territorio izquierdo del Ebro, la primacía de Toledo, y mucho menos en los estados de la Corona de Aragón». ${ }^{42}$

El más antiguo episodio de rebeldía, aunque muy breve, fue protagonizado por el primer arzobispo compostelano, el astuto y ambicioso Diego Gelmírez, enfrentado en los primeros meses del año $1124^{43}$ con Bernardo, arzobispo de Toledo, en un momento en que ambos ostentaban el título de legados pontificios, el compostelano en su provincia y el toledano en toda España. Don Bernardo prohibió a don Diego celebrar concilios fuera de su metrópoli y le mandó que le obedeciese como su primado. Don Diego le recordó que él también era legado, y que, puesto que su iglesia era exenta, no le iba a obedecer ni como primado, ni como legado ni como arzobispo. ${ }^{44}$ De todas maneras, tal disputa acabó pronto con el fallecimiento en abril de ese mismo año 1124 del arzobispo toledano.

40 E incluso Narbona si se sigue el criterio de la España visigoda, puesto que la metrópoli de Narbona formaba parte del reino de Toledo (sólo tenía dos sedes en el reino franco, Toulouse y Uzès). Sobre la provincia narbonense, que en época carolingia incluía los obispados catalanes de Gerona, Barcelona, Vic, Urgell y Elna, cf. Feige 1991 y Vones Liebenstein 2013.

41 Cf Feige 1991: 61-132.

42 Cf. Gorosterratzu Jaunarena 1925.

43 Recuérdese que este momento, correspondiente a los últimos años del reinado de doña Urraca, fue una época de guerra civil en el reino, lo que alentó todo tipo de conflictos.

44 Cf. Flórez 1765: libro II, cap. LXVI, 404-409. 
El 24 de abril de 1139 se produce un hecho singular en la historia del conflicto por la primacía hispana: ese día Inocencio II expidió la primera orden expresa a los arzobispos hispanos para que prestasen obediencia al arzobispo de Toledo. ${ }^{45}$ Las reacciones a este mandato llegaron rápidamente. En efecto, el arzobispo de Braga ${ }^{46}$, en el año 1143, es el actor del primer acto de insumisión formal con respecto al primado toledano ${ }^{47}$, coincidiendo con el establecimiento formal del reino portugués y su reconocimiento por Alfonso VII muy poco antes, en 1143.48 El metropolitano de Tarragona también se negó a acatar la primacía de Toledo en 1148, en un momento en el que tomaba fuerza la corona catalano-aragonesa. ${ }^{49}$

Por su parte, llegados a mediados del siglo XII, don Pelayo, nuevo arzobispo de Santiago de Compostela, también contradijo el reconocimiento de la primacía toledana, consiguiendo incluso de Anastasio IV, en un documento de fecha incierta ${ }^{50}$, pero que debe situarse en 1153 o primeros meses de 1154, la exención de la «potestad del arzobispo de Toledo" y el permiso para llevar la cruz alzada en las visitas a su provincia, e incluso por otras provincias (la bracarense) cuando iba de camino a una sede de su metrópoli. ${ }^{51}$

Sin embargo, dicha exención perduró escasamente un año. El 8 de abril de 1154 el propio Anastasio IV mandó al cardenal legado Jacinto Bonone ${ }^{52}$ que ordenase a los arzobispos de Compostela, Braga y Tarragona que se sometieran a la primacía del metropolitano toledano. ${ }^{53}$ Poco después, el 1 de mayo de dicho año 1154, Anastasio IV volvió a pedir al legado Jacinto que se ocupase de que los arzobispos de Braga, Tarragona y Compostela demostrasen la obediencia

45 Ed. por Mansilla Reoyo 1955: 85, núm. 68.

46 Para conocer el contexto, cf. Mansilla Reoyo 1961.

47 Una excelente visión de las disputas habidas entre Toledo y Braga desde los orígenes hasta principios del siglo XIII puede consultarse en: Feige 1991.

48 De todos es conocido que Alfonso Henríquez fue proclamado por sus tropas rey de Portugal en 1139, tras la victoria sobre los almohades en la batalla de Ourique. El "emperador» Alfonso VII le reconoció su título de rey en el Tratado de Zamora, que tuvo lugar los días 4 y 5 de octubre de 1143, en presencia (lo cual es muy significativo) del legado papal, el cardenal diácono de San Cosme y San Damián, Guido de Vico. Ese mismo año Alfonso I prestó vasallaje al papa y enfeudó su reino, encomendándose a la protección papal.

49 Recuérdese que Ramiro II de Aragón casó a su hija única Petronila con el conde Ramón Berenguer IV de Barcelona en 1137, tras lo cual renunció de hecho al gobierno de su reino (hasta su muerte en 1157), que ejerció su citado yerno. Con el hijo de estos dos últimos, Alfonso II, se producirá la unión definitiva entre el reino de Aragón y el condado de Barcelona.

50 Cf. Jaffé 1885-1888: núm. 9808. Editado por Mansilla Reoyo 1955: 107-108, núm. 91, afirmando: sancimus ut tam tu quam tui deinceps sucessores nulli metropolitano seu primati, preter Romanum Pontificem, subiecti estis vel obedientiam exhibere cogamini.

51 Unos años antes, en 1145, el arzobispo de Compostela, don Pedro, ya había recibido de Eugenio III un privilegio muy singular: el derecho de visitar su provincia con una cruz alzada antes de su persona, al estilo de los primados. Cf. Jaffé 1885-1888: núm. 9363. Dice el diploma: Ad maiorem quoque ecclesie ipsius venustatem et persone tue decorem, cum per tuam provinciam de loco ad locum te ire contingerit, et pertransire alias provincias seu loca necesse habueris, cruem quam ex Apostolice Sedis permissione ante te baiulas, tibi tuisque successoribus continue deferendi licentiam indulgemus.

52 Sobre este personaje, cf. Weiß 1995.

53 Cf. Jaffé 1885-1888: núm. 9859. Ed. por Mansilla Reoyo 1955: 113-114, núm. 95. debida al prelado compostelano ${ }^{54}$, aunque este último no la había prestado todavía a principios de 1155 , cuando coincidieron ambos arzobispos hispanos en el concilio celebrado en Valladolid y presidido por el cardenal Jacinto. ${ }^{55}$

Poco más tarde, el 9 de febrero de $1156^{56}$, Adriano IV confirmó de nuevo la primacía toledana y declaró expresamente sin efecto el citado privilegio de Anastasio IV por el que eximía al metropolitano compostelano de obedecer la primacía del toledano, argumentando como causa para esta nulidad que tal documento había sido expedido sin oír atentamente el consejo de los cardenales de la curia. ${ }^{57}$

En fin, estas pretendidas «rebeldías» de Compostela se producían en un momento histórico en que tanto Toledo como Compostela estaban integradas en el mismo reino, por lo que se ha visto en ello el reflejo de un enfrentamiento interno entre dos ciudades rivales que querían tener y conservar el máximo prestigio en el mismo. ${ }^{58}$ Pero la realidad es que, tras la separación de los reinos de Castilla y León en 1157, la situación de conflicto continuará. Durante el reinado del monarca Fernando II de León (1157-1188), que concedió numerosas mercedes a la Iglesia de Santiago ${ }^{59}$, el metropolitano compostelano se negó a prestar obediencia formal al primado toledano, concretamente entre los años 1168 y 1172, de tal modo que en este año 1172 el cardenal legado Jacinto amenazó nada menos que con la suspensión canónica a los sufragáneos de Compostela que no reconociesen el primado toledano. ${ }^{60}$

Como se deduce fácilmente de un análisis de los hechos, las razones para la insumisión son fundamentalmente políticas, ya que los arzobispos de Braga, Tarragona y Compostela, siendo las máximas autoridades eclesiásticas respectivamente de los reinos de Portugal, ${ }^{61}$ Aragón $^{62}$ y

54 Cf. Jaffé 1885-1888: núm. 9901.

55 Celebrado aproximadamente entre los días 25 de enero y 4 de febrero de dicho año 1155. Cf. Erdmann 1927: 55-60, núm. 5. Parece que en esta asamblea no se trató el tema de la primacía.

56 Ed. por Mansilla Reoyo 1955: 118-119, núm. 100. Sin embargo, la fórmula para esta confirmación es atípica, y dio lugar a problemas ulteriores: "sicut ecclesia tua ex antiquo habuit in tota Hispaniarum regione primatu, sic tu (...) eundem primatum (...) debeas obtinere».

57 "Adiicentes ut privilegium quod frater noster Pelagius, Compostellanus archiepiscopus, a predecessore nostro bone memorie Anastasio, Papa (IV), quod iure primatus non deberet tibi (Toletano archiepiscopo) esse subiectus, dicitur impetrasse, nullas habeat vires in posterum, nec aliquod tibi debeat preiudicium irrogare; sed privilegium iam dicti antecessoris nostri sancte recordationis Eugenii, Pape (III) tibi super concessione primatus indultum, illi modis omnibus preiudicare decernimus; presertim, cum illud Anastasii (IV) neque de communi neque de sanioris partis fratrum consilio fuisset elicitum». Poco más tarde, el 11 de julio de 1163, Alejandro III reconocía expresamente el primado de Toledo sobre dos provincias eclesiásticas, Braga y Compostela, y volvía a declarar sin valor el privilegio de Anastasio IV favorable a Compostela, con la misma fórmula usada por Adriano IV (ed. por Mansilla Reoyo 1955: 128-129, núm. 110).

58 Cf. Herbers 2006: 87-88. Por su parte, Feige 1991: 116, afirma lo siguiente: «En agosto de 1157 murió Alfonso VII y con él murieron las ideas del imperio y de la primacía».

59 Recuérdese que tanto Fernando II como Alfonso IX de León se enterraron en la catedral de Santiago.

60 Ed. de Mansilla Reoyo 1955: 115-116, núm. 97 (aunque lo fecha por error en 1155).

61 Véanse los interesantes estudios de Branco 2011 y de Cunha 2013.

62 Véase la obra clásica de Sucona i Vallès 1899. 
León ${ }^{63}$, se negaban a acatar a un arzobispo de otro reino, el de Castilla, en el que, además, éste era canciller, consejero real y señor de inmensos territorios. A este respecto, es muy significativa la protesta elevada a la curia de honorio III por el procurador del cabildo de Braga contra las «desorbitadas pretensiones» de Toledo ${ }^{64}$ :

super provinciam Narbonensem, super comitatum Barchinonensem, super regnum Aragonie, super regnum Navarre, super regnum Castelle, super regnum Legionense, super regnum Portugallie, super totam terram quam adhuc habent sarraceni in Hispania.

Otros autores ya han demostrado documentalmente la oposición regia a que los prelados de su reino estuviesen sometidos a un arzobispo o primado residente en otra corona. Es conocida la resistencia mostrada por Alfonso VI, rey de Castilla y León, en 1096, a que el obispo de Burgos estuviese bajo el metropolitano de Tarragona, por Fernando Il de León a que el ordinario de Zamora quedase sujeto al arzobispo de Braga, o por Jaime I de Aragón a que la sede de Valencia se incluyese en la provincia eclesiástica toledana. ${ }^{65}$ A lo largo del siglo XII, en palabras del profesor López Alsina, "se alcanza un equilibrio entre la auctoritas del Papado sobre la Iglesia universal y la potestad del rey sobre sus obispos y la iglesia de su reino. Los obispos se identifican con su rey, incluso por encima del marco de la provincia metropolitana, y el rey (...) proclama el origen divino de su delegación para gobernar las iglesias de Dios». ${ }^{66}$

Además de los citados motivos socio-políticos que propiciaban tal resistencia y desacato a la primacía, hay que tener en cuenta también en esta situación las aspiraciones y ambiciones humanas, más o menos nobles, de unos y otros altos eclesiásticos, que, quizá con razones de fondo, se manifestaron muy claramente en algunos momentos, como a continuación se verá.

Pero, como afirma Rivera Recio ${ }^{67}$ con gran acierto, «/a prolongada resistencia unánime de los metropolitanos (rebeldes) acabó por dar a éstos la victoria, en el sentido de que desde el último cuarto del siglo (xII el Pontífice) deja de imponerles la sumisión y acatamiento al primado. Lo que Urbano II quiso que fuera una institución efectiva se convertiría antes de que transcurriera un siglo en una dignidad honorífica ${ }^{68}(. .)$.

Por otra parte, hay que recordar que Compostela no sólo estuvo enfrentada con Toledo, sino también con el metropolitano de Braga. ${ }^{69}$ Durante todo el siglo XII hubo una notoria disputa entre ambas sedes, basada en el hecho de que el prelado compostelano poseía la mitad de la ciudad de Braga

\footnotetext{
63 Sobre la protección regia a la Iglesia de Santiago, véanse documentos muy significativos en: López Ferreiro 1898-1911 IV: Apénd. 72-172. Cf. además González Vázquez 1996, 93-133.

64 Del año 1217. Comentado por Feige 1978: 405-406, y por Henriet 2004: 292-293.

65 Cf. ibídem: 292.

66 López Alsina 2013: 105-131, esp. 127.

67 Cf. Rivera Recio 1973: 2026.

68 En efecto, los mandatos pontificios antes comentados para que los arzobispos hispanos prestaran «obediencia» al primado de Toledo, típicos de la primera mitad del siglo XII, se convierten paulatinamente, en la segunda mitad de esa centuria, en órdenes para demostrar «reverencia», desapareciendo a partir de 1172 .

69 Véase el estudio citado de Branco 2011.
}

y las parroquias de San Víctor y San Fructuoso de esta localidad. Desde un primer diploma pontificio dado por Pascual II en $1103^{70}$, hasta un arreglo definitivo en época de Inocencio III, en $1199^{71}$, la controversia fue continuada, resultando en ella "triunfador» el prelado bracarense. Ese mismo año 1199 Inocencio III aprobaba una concordia concertada entre Braga y Santiago, por la cual Lamego e Idanha-Guarda quedaban incorporados a Compostela, mientras que Coímbra y Viseu pasaban a la metrópoli de Braga. ${ }^{72}$

En fin, llegado el siglo XIII, igual que en la centuria anterior, los metropolitanos de Tarragona, Compostela y Braga se seguían resistiendo a acatar la primacía de la Iglesia toledana. Pero el arzobispo de Toledo no se resistía a ello. De hecho, poco antes de la celebración del IV Concilio de Letrán, concretamente el 1 de junio de 1211, Inocencio III contestaba a una queja que le había formulado al respecto el arzobispo toledano Rodrigo Jiménez de Rada, y le comunicaba que, ante el peligro de la invasión almohade en la península, no le parecía conveniente originar otro «escándalo» con motivo de las luchas por la primacía. ${ }^{73}$

Pero don Rodrigo tampoco se rindió ante tal intempestiva contestación papal. Un año después de haber recibido tal respuesta, concretamente el 16 de julio de 1212, los ejércitos cristianos de Castilla, Aragón y Navarra derrotaron a los almohades en la famosa batalla de Las Navas de Tolosa. Para la financiación de tal campaña se recurrió en gran medida a las rentas de la Iglesia castellana, que durante ese año 1212 entregó nada menos que la mitad de sus beneficios para la lucha. ${ }^{74}$ El arzobispo de Toledo, don Rodrigo, participó personalmente en los preparativos de dicha batalla ${ }^{75}$, en la predicación de la cruzada para la misma, y muy especialmente dirigiendo desde la villa de Calatrava las operaciones militares que desde 1212 hasta el año 1214 se mantuvieron contra los musulmanes. ${ }^{76}$

Armado de sus argumentos de siempre, pero con este bagaje y prestigio alcanzados en la lucha contra los almohades, el arzobispo de Toledo compareció en Roma, rodeado de numerosos canónigos y familiares ${ }^{77}$, preparado para asistir al IV Concilio de Letrán. Como es sabido, el Concilio se inauguró el 11 de noviembre de 1215, pero los días anteriores tuvieron lugar unas tomas de contacto y unos coloquios destinados a despachar asuntos secundarios. ${ }^{78} \mathrm{En}$ esas sesiones don Rodrigo volvió a reclamar, en un largo discurso (pronunciado nada menos que en siete idiomas: latín, italiano, alemán, francés, inglés, vascuence y castellano, según las crónicas) $)^{79}$, la confirmación de la primacía toledana

\footnotetext{
70 Ed. por Erdmann 1927: 159, doc. núm. 5.

71 Ed. por Mansilla Reoyo 1955: 251, doc. núm. 215.

72 Ed. por ibídem: 230-240, núm. 204, con fecha de 12-VII-1199.

73 Cf. ibídem: 482-483, núm. 455; y Hernández 1996.

74 Cf. Linehan 1975: 5.

75 Cf. Cirot 1912. El autor de la misma parece ser el obispo Juan de Osma (1231-1240).

76 Cf. Pyck 2004.

77 Dicho arzobispo llevaba consigo hasta 16 acompañantes. Cf. Luchaire 1905.

78 Entre ellos, la confirmación de la elección de Federico II como rey del Sacro Imperio (sería coronado el 22-XI-1220), o la ratificación de la suspensión del primado de Canterbury.

79 Este discurso ha sido estudiado en profundidad, desde el punto de vista de la «historia de las ideologías», por Henriet 2004: 296 y ss., demostrando que lo político y lo religioso se entremezclan irremediablemente en la historia.
} 
sobre toda la península ${ }^{80}$, que le negaban obstinadamente los arzobispos de Braga, Compostela, Tarragona y Narbona. Don Rodrigo Jiménez de Rada ${ }^{81}$ se quiso presentar en esta asamblea como un dignatario eclesiástico de la categoría de los patriarcas de Constantinopla o Jerusalén..$^{82} \mathrm{El}$ antes citado ms. 42-21 de la Biblioteca Capitular de Toledo afirma lo siguiente ${ }^{83}$ :

(...) Notum igitur sit omnibus hominibus presentem paginam inspecturis quod, cum dominus Innocentius, Papa III, celebraret Generale Concilium apud Lateranum, anno Incarnationis Dominice Mำ CCo XVo, venit ad idem Concilium Rodericus, Toletane sedis archiepiscopus, Hyspaniarum primas, et, impetrata audientia ab eodem Papa, proposuit pleno consistorio coram ipso et cardinalibus et pluribus archiepiscopis et episcopis et abbatibus et canonicis et aliis clericis querimoniam de Bracharensi et Compostellano et Terraconensi et Narbonensi archiepiscopis, quod nolebant ei tamquam primati suo obedire (...)

No sólo autores antiguos (Flórez ${ }^{84}$, Fuente ${ }^{85}$, etc.), sino también otros del siglo $\mathrm{XX}$, como Fita ${ }^{86}$ o López Ferreiro ${ }^{87}$ han negado la veracidad de esta intervención, aduciendo que los textos que se conservan de la misma son una burda falsificación posterior, y tratando de demostrar que ni el arzobispo toledano ni el compostelano asistieron al Concilio. ${ }^{88}$ Sin embargo, los actuales estudiosos tienen por cierta la asistencia de los citados 27 obispos hispanos al Concilio, entre ellos los ordinarios de Toledo ${ }^{89}$ y Santiago, así como la discusión sobre la primacía hispana en los preliminares de la celebración de tal asamblea, con una intervención muy especial del prelado toledano.

Efectivamente, el citado arzobispo toledano, Rodrigo Jiménez de Rada, en presencia del papa, de los cardenales y de otros muchos prelados, mostró los privilegios de los papas Gelasio II, Honorio II, Lucio III, Adriano IV, del legado Jacinto Bobone y del propio Inocencio III que la Iglesia de Toledo tenía y que demostraban la primacía del metropolitano toledano sobre toda la península. ${ }^{90}$ Del discurso del arzobispo don Rodrigo, como es bien sabido por los historiadores y canonistas, hay dos versiones: una

80 Lo que no ocurrió en todos los concilios generales latinos (hubo doce Concilios entre los siglos XII y XVI). Por ejemplo, es sabido que no se tocó el tema en las larguísimas sesiones del Concilio de Trento (1545-1563).

81 Sobre este prelado, véase el estudio clásico y documentado de Gorosterratzu Jaunarena 1925.

82 En el ms. Vitr. 15-5 de la Biblioteca Nacional (que un poco más adelante se comentará), en el fol. 22, es significativamente representado el metropolitano de Toledo rodeado a la misma altura por los citados patriarcas, y teniendo por debajo a los arzobispos de Compostela, Tarragona, Braga y Narbona.

83 Cf. Rivera Recio 1951: 336-337

84 Flórez 1748: 85-96.

85 Fuente 1873-1875: 47.

86 Fita Colomé 1902: 35 y ss.

87 López Ferreiro 1898-1911, V: 68-69.

88 Hay que decir que Fita aún no conocía la citada lista de obispos asistentes al Concilio conservada en la Biblioteca cantonal de Zurich.

89 Demostrada documentalmente por Duchesne 1900; y por Gorosterratzu Jaunarena 1925: 160-184. Véanse también los argumentos aportados por García Villoslada 1953: 586-592.

90 No presentó otros diplomas pontificios también favorables a la primacía, pero que usaban unas fórmulas de dudosa interpretación, como uno expedido por Alejandro III el 11 de diciembre de 1166, editado por Mansilla Reoyo 1955: 130-132, núm. 112. corta $^{91}$ y otra más extensa. ${ }^{92}$ Veamos en primer lugar cómo resume su intervención la versión reducida ${ }^{93}$ :

(archiepiscopus Toletanus) ad probandum se suum esse primatem, ostendit et legit privilegia Honorii, Gelasii, Lucii, Adriani et eiusdem Innocentii tertii, Romanorum Pontificum, in quibus continebatur et manifestissime probatur Toletanum archiepiscopum esse primatem Hyspaniarum. Addidit etiam idem archiepiscopus Toletanus se habere alia plura privilegia et munimenta et scripta que osteredet ipse, in quibus probatur ipsum esse primatem Hyspaniarum. Ostendit etiam eadem die et legit ibidem sententiam lacinti cardinalis, Apostolice Sedis legati, latam in archiepiscopum Bracharensem nisi Toletano archiepiscopo tamquam primati tuo obediret; legit etiam executionem eiusdem lacinti missam suffraganeis ecclesie Compostellane, in qua eis precipiebat ut Toletano archiepiscopo tamquam primati suo debitam obedientiam et reverentiam exhiberent.

Además, conocemos parcialmente cómo fueron las discusiones conciliares en torno a la primacía hispana gracias a una crónica redactada por un alemán presente y testigo del Concilio, conservada en la Universidad de Giessen. ${ }^{94}$ En ella se indica que la controversia había comenzado antes de la celebración del Concilio, y que el día tercero en el desarrollo de las sesiones conciliares, esto es, el 13 de noviembre de 1215 , el papa intentó en vano solucionar el litigio. La crónica afirma textualmente:

Tertia vero die litem quae inter Compostellanum et Toletanum episcopos super obtinendo primatum hucusque duravit, dominus Papa dirimere et rationabiliter inde diffinere conabatur.

Sabemos que a la tesis toledana se oponía en especial el arzobispo de Braga, Estêvão Soares da Silva, manifestando que le parecía escandaloso que, con motivo de tal primacía, se obligase a todos los reyes hispanos a someterse al Reino de Castilla. Pero también mostró su desacuerdo Pedro Muñiz ${ }^{95}$, arzobispo de Compostela. Veamos cómo lo refleja la llamada «versión corta» de dicho discurso ${ }^{96}$ :

Bracharensis autem archiepiscopus, qui fuerat ad hoc citatus, sicut sibi fuit postea per ipsum Papam et testes legitimos sufficienter probatum, respondit iam dicto

91 Conservada en el citado ms. 42-21 de la Biblioteca Capitular de Toledo. Véase en Fita Colomé 1902: 40-43; y Rivera Recio 1951: 336-337.

92 Conservada, con redacciones no exactamente coincidentes, en dos manuscritos custodiados antiguamente en la Biblioteca Capitular de Toledo, y que en la actualidad se guardan en la Biblioteca Nacional (Madrid): Vitr. 15-5 (titulado «Liber privilegiorum super primatu Toletanae ecclesiae», del año 1253, con añadidos de la segunda mitad del siglo XIII y del siglo XIV), ff. 22-23v; y ms. 10.040 (titulado «Liber privilegiorum super primatu Toletanae ecclesiae», del siglo XIV), ff. 20-22. Esta versión ya fue editada hace más de cuatro siglos, aunque con retoques, por Loaysa y Girón 1595: 287-292; y luego por Mansi 1778. XXII: cols. 1071-1075. Véase una buena edición (a pesar de considerarlo un texto espurio) por Fita Colomé 1902: 182-185. Véase también la edición de García y García 1987.

93 Ed. por Fita Colomé 1902: 41.

94 Se trata del ms. 1105 de la Universitätsbibliothek de Giessen, del que nos interesan los folios 59-60v. Véase el artículo de Kuttner y García y García 1964.

95 Sobre este personaje, cf. Cavero Domínguez 2015. La autora expresa que no se puede asegurar con certeza su participación directa en el Concilio.

96 Cf. Fita Colomé 1902: 41. 
archiepiscopo Toletano contestando litem in presentia eiusdem Pape. Compostellanus vero respondit ei eadem die quod quamvis ipse esset primas Hyspaniarum, quod erat falsissimum, non tamen sui suffraganei deberent ei in aliquo obedire; unde dictum fuit a multis et creditum quod ipse Compostellanus taliter respondendo litem fuerat contestatus (...)

En la versión «larga» de este discurso, y en relación con las protestas que ahora nos interesan del prelado compostelano ${ }^{97}$, se percibe que tales descontentos se basaban, más que en pruebas o argumentos legales, reales y fehacientes, en el recuerdo de la antigua importancia de una sede de Compostela muy antigua y "apostólica» ${ }^{98}$; a lo que respondió el toledano don Rodrigo con similares razonamientos, argumentando que la sede metropolitana de Santiago tenía sólo cien años de antigüedad, por lo cual las pretensiones de grandeza de Compostela no se sostenían por motivos temporales, mencionando, además, que la catedral de Santiago no era hasta poco tiempo atrás más que una pequeña «iglesucha». Por contra, Jiménez de Rada reivindicaba la vetustez de la Iglesia toledana, fundada según él (ien el siglo ı!) por San Eugenio ${ }^{99}$, discípulo de San Pablo, y «visitada en persona» nada menos que por la Virgen María ${ }^{100}$ :

Compostellanus similiter eadem die, in pleno Consistorio, respondit: "Pater Sancte, certe derisoria videtur petitio domini Roderici, quia ecclesia Compostellana ita antiqua, ita nobilis fundata in honore apostoli lacobi, Domini consanguinei, qui primo in Yspania verbum Domini seminavit, et infinitos ad fidem Christi convertit, cuius corpus in eadem ecclesia requiescit, nunc, quod absit, inpetat obedire ecclesie Toletane». Dominus autem Rodericus, archiepiscopus Toletanus, petita et obtenta a Domino Papa licentia, respondit: "Pater Sancte, o! utinam causa ista in rationibus a parte reverendi fratris archiepiscopi Compostellani nunc propositis remaneret, et alie undique allegationes cessarent, maxime si per predicta universa vel singula credat se posse defendere Toletane ecclesie non teneri. Si petitio mea derisoria videatur, bene credo insipient non tamen sapienti. Si antiquitatem Compostellane ecclesie allegat antiquitas, ista in centum annorum spacio continetur quod sic probo. Dominus Calixtus Papa (II), ad instantiam principis, cleri et populi Yspanie, metropoliticum ius antique et famose civitatis Emeritensis transtulit anno Domini Mo Co XXo IIIIo; tum, quia civitas Emeritensis erat sub dominio sarracenorum constituta; tum, ob reverentiam beati lacobi, cuius corpus ibidem creditur esse sepultum de bono in melius pullularet; nam usque ad hec tempora oratorium quoddam parvissimum erat locus ille in quod nunc sit est ecclesia Compostellana. Antiquior est ergo ecclesie Toletana, que fundata est a tempore Eugenii, Pauli apostoli discipuli. Si nobiltatem allegat, propter invocationem beati lacobi, certe cuiuscumque sancti nomine ecclesia tituletur nobilis est maxime apostolorum; set nobilior omnibus que beate Virginis nomine decoratur, precipue Toletana ecclesia quam ipsa beata Virgo corporaliter dignata est visitare, cum quondam beato Ildefonso, archiepiscopo Toletano, sacrificium Domino offerenti, se eidem visibilem redidit (...)»

97 No nos detenemos ahora en la argumentación del metropolitano de Braga.

98 Para contextualizar la situación, cf. Herbers 1994.

99 Una reliquia del (supuesto) brazo de este santo había sido traída desde St. Denis en 1156.

100 Ed. por Fita Colomé 1902: 190-195.
A continuación, ambos arzobispos, el de Compostela y el de Toledo, se enzarzaron aún más con tales discusiones, enmarañando los razonamientos, para sorpresa del pontífice y de los demás asistentes al Concilio. El metropolitano toledano afirmó entonces que el apóstol Santiago tenía poca importancia para España, ya que nunca había estado allí en vida ("Quomodo ergo in Yspania predicavit, si nondum intravit?»), y que, de haberla visitado, se decía que sólo había podido convertir a una pobre mujer anciana («unam tantum mulierem vetulam sua predicatione convertit»), poniendo incluso en duda que el cuerpo del apóstol yaciera en Compostela, puesto que algunos afirmaban que estaba enterrado en Jerusalén («quidam dicunt quod Iherosolimis requiescit corpus eiusdem Apostoli»). Además, el prelado de Toledo, que llegó a interpretar negativamente las peregrinaciones a Compostela, oponía al prestigio de la supuesta tumba del apóstol Santiago en Compostela el hecho más relevante de que la Virgen María hubiera descendido en persona a la catedral de Toledo.

Tales disquisiciones pueden parecer "bizantinas», esto es, sutiles, intempestivas o baldías. Pero sólo lo parecen: se deduce de todo ello la existencia de dos teorías dispares para justificar la relevancia de una y otra sede: Compostela basaba su prestigio casi exclusivamente en la posesión de las reliquias del Apóstol Santiago ${ }^{101}$, mientras que Toledo fundamentaba su ascendiente en ser una ciudad regia, habitada desde épocas muy antiguas por monarcas y arzobispos «bajo el patrocinio universal de la Virgen», y, muy señaladamente, en la preponderancia que le atribuían algunos (aunque escogidos) diplomas pontificios.

Oídos tales argumentos y pensado el asunto con sus cardenales, Inocencio III optó por no decidir sobre el debate, seguramente acogiéndose a un error procesal de forma, ya que, tal como habían manifestado los arzobispos de Braga y Narbona, en la convocatoria del Concilio no se hacía mención a este punto. El pontífice decidió dejar pasar un tiempo sin dar una solución definitiva a este largo litigio hispano, que iba por caminos tan tortuosos. Como afirma Gorosterratzu, "Jiménez de Rada regresó a principios de 1216 a España, sin haber obtenido la sentencia apetecida sobre su gran pleito de la primacía de Toledo, según están acordes las discutidas actas y más de una docena de bulas pontificias desde 1216 a 1218». ${ }^{102}$

El texto toledano que se está comentando ${ }^{103}$ refleja así la decisión final del papa, tras la intervención de don Rodrigo Jiménez de Rada en el Concilio Lateranense, que podríamos denominar una solución de compromiso, por la cual designaba al metropolitano de Toledo legado pontificio en la península ibérica durante 10 años $^{104}$ y le reconocía su

101 Véanse los comentarios a ello de Herbers 2006: 87-88.

102 Gorosterratzu Jaunarena 1925: 176.

103 Ed. por Fita Colomé 1902: 184.

104 Aparece, en efecto, como legado pontificio entre los años 1219 y 1221 (con una legación bastante efímera en cuanto a su duración y a su contenido), en los siguientes diplomas papales: 9 de febrero a 20 de marzo de 1219 (cf. Mansilla Reoyo 1965: 160-164, núms. 207 a 212); 29 de abril de 1219 (ibídem: 170, núm. 223); 21 a 28 de mayo de 1219 (ibídem: 173-174, núms. 228 y 229); 17 de julio de 1219 (ibídem: 175176, núm. 232); 5 de diciembre de 1219 (ibídem: 200-201, núm. 257); 4 y 5 de febrero de 1220 (ibídem: 207-208, núm. 268 y 269); 4 de marzo de 1220 (ibídem: 211, núm. 274); 21 de mayo de 1220 (ibídem: 217218, núm. 285); 4 de julio de 1220 (ibídem: 226-227, núm. 301); 15 de 
primado sobre la ciudad de Sevilla, cuando ésta cayera en poder de los cristianos:

In eodem autem Concilio (archiepiscopus Toletanus) obtinuit per decennium, iuxta petitionem suam, legationem officium in Yspaniam exercere (...) Optinuit etiam quod quam cito civitas Yspalensis redderetur cultui christiano, sine strepitu iudicii et de plano iure, primatus subesset ecclesie Toletane (...)

¿Qué pasó una vez que los padres conciliares regresaron a sus respectivas sedes? Sabemos que en los años siguientes el pontificado se posicionó tímidamente a favor de mantener los derechos de primacía "honorífica» de la Iglesia toledana, pero, según parecen indicar los diplomas de aquellos años, sin «implicarse» demasiado en un amparo a ultranza de la misma. ${ }^{105}$ Dos meses después de la finalización del Concilio IV de Letrán, el 12 de enero de $1216^{106}$, Inocencio III citaba formalmente ante la Audiencia Romana, para el día 1 de noviembre de 1216, a los procuradores del arzobispo y del cabildo de Braga, que seguían rehusando la primacía toledana, para que defendieran con datos y con hechos su postura. Efectivamente, el metropolitano que más objeciones puso a la primacía, finalizado el Concilio, era el de Braga $^{107}$, aunque, como después se verá, también el arzobispo de Compostela, unos veinte años más tarde, pleiteó con Toledo por el mismo asunto.

Fallecido Inocencio III ese año 1216, los pontífices que le sucedieron, Honorio III y Gregorio IX, mantuvieron una postura en principio favorable pero en la práctica dubitativa en la cuestión de la primacía toledana. Véanse nuevamente estas palabras del doctor Rivera Recio: "Honorio III, ante las insistencias del toledano y para evitarse extender nuevos documentos, encontró el expediente de hacer copiar de los Registros Vaticanos la documentación anterior, que era remitida al arzobispo y cabildo de Toledo; expediente éste que fue reiteradamente utilizado por Gregorio IX, quien incluye, además, entre los territorios sometidos (...) las comarcas recién conquistadas a los árabes». ${ }^{108}$

En efecto, Honorio III, a los pocos días de ascender al solio pontificio, concretamente el 12 de agosto de 1216, renueva la citación a los procuradores bracarenses que había hecho poco antes su predecesor. ${ }^{109}$ Tales procuradores no se presentaron en el plazo fijado, sino más tarde y sin la documentación precisa. Honorio III, acogiéndose a este incumplimiento procesal, podía haber dado un golpe de mano y zanjar definitivamente la cuestión a favor de Toledo, pero prefirió tratar de quedar bien con las dos partes, y un

septiembre de 1220 (ibídem: 239-240, núm. 323); 22 de septiembre de 1220 (ibídem: 242-243, núms. 326 y 327); y 24 de noviembre de 1221 (ibídem: 284, núm. 381).

105 De hecho, desde Roma no se volvió a anunciar ni a dictar ningún castigo ejemplar a quienes se opusieran a la misma.

106 Cf. Hernández 1996: 533, núm. 653. Véanse también los docs. núms. 654 y 655.

107 Cuyos argumentos se basaban en que Toledo no podía demostrar haber tenido «antiguamente» la primacía, por lo que los papas no le podían ratificar algo que nunca había poseído. A ello respondió Toledo falsificando las fuentes para demostrar su primacía en época visigoda. Cf. Linehan 1988; y Feige 1988.

108 Cf. Rivera Recio 1973: 2026; y Cf. Hernández 1996: 538-539, núm. 668; y 544-545, núm. 685.

109 Cf. ibídem: 534, núms. 656 y 657 . Véase también el doc. núm. 658. año más tarde, en 1217 , volvió a fijar otra fecha para su comparecencia. ${ }^{110}$

En enero de 1218, por toda respuesta al conflicto, el papa extendió una copia para el arzobispo toledano de las «bulas» de Gelasio II, Pascual II, Eugenio III y Urbano II que ratificaban la primacía toledana. ${ }^{111}$

Durante el pontificado de Gregorio IX (1227-1241) los pleitos por la primacía se mantuvieron. En este momento es fundamentalmente la sede arzobispal de Compostela la que se negaba a reconocer el derecho de primacía del toledano. En septiembre de $1231^{112}$ el arzobispo y el cabildo de Toledo elevaron una reclamación ante el papa «quod venerabilis frater archiepiscopus et dilecti filii capitulum Compostellani super obedientia, reverentia et aliis qua iura primatie contingunt iniuriantur eisdem", motivo por el cual el pontífice comisionó al obispo y a dos canónigos de Burgos para que estudiasen la queja. Tres años después, en mayo de 1234, Gregorio IX comisionó a los obispos de Segovia, Salamanca y León para que reuniesen los datos necesarios y se los enviasen a la curia romana en este litigio mantenido entre Compostela y Toledo. ${ }^{113}$ Pero las presiones de una y otra parte y la pusilanimidad de los jueces delegados pontificios provocaban que el proceso se eternizase. Visto que estos tres prelados no habían llegado a ninguna conclusión firme sobre el tema, Gregorio IX procedió por tercera vez a nombrar otra comisión en enero de 1236, siendo designados entonces como jueces los obispos de Burgos, Segovia y Salamanca. ${ }^{114}$

Gregorio IX recurrió poco después a la misma solución que había utilizado Honorio III. Nadando entre dos aguas, en 1239 envió en tres ocasiones al arzobispo de Toledo copia de las «bulas» antiguas que atestiguaban dicho derecho de primacía de la mitra toledana. ${ }^{115}$ Era una decisión que equivalía a decir al metropolitano toledano que tenía razón en sus pretensiones, pero que la curia apostólica no se quería significar demasiado en su ayuda.

El paso del tiempo y la entrada en una etapa histórica nueva, más allá de la Alta Edad Media, así como la actitud distante del pontificado con respecto a una situación que le contrariaba, sirvieron para apaciguar los ánimos, de tal manera que las querellas por la primacía hispana fueron cada vez más escasas y más distantes en el tiempo. ${ }^{116}$

110 Cf. ibídem: 536, núm. 661.

111 Ed. por Mansilla Reoyo 1965: 93-96, núms. 119-123. Cf. también Hernández 1996: 537-538, docs. núms. 663-666.

112 Ed. por Domínguez Sánchez 2004: 201, núm. 201.

113 Ed. por ibídem: 306-307, núm. 350.

114 Ed. por ibídem: 433-434, núm. 528. Véase también el doc. núm. 557, con fecha de 7-V-1236.

115 Cf. Hernández 1996: 547-548, núms. 693-695. Ed. por Domínguez Sánchez 2004: 662-665, núm. 843; 667-670, núm. 846; y 676-677, núm. 856.

116 En 1245, ante un rebrote del litigio por la primacía entre los arzobispos de Toledo y Braga, Inocencio IV comunica al toledano, en la misma línea que habían mantenido Honorio III y Gregorio IX, que vuelve a aplazar su decisión final al respecto, con el argumento de no causar daños al prelado bracarense recientemente elegido (João Egas) (cf. Quintana Prieto 1987: 106-107, núm. 95. En 1267 se suscitó de nuevo la cuestión de la primacía cuando el arzobispo de Toledo la reivindicó en su paso por la provincia eclesiástica de Narbona (cf. Domínguez Sánchez 1996: 272-273. Sin embargo, en 1274 el arzobispo de Tarragona (Bernat d'Olivella) reconoce que el pleito de primacía con Toledo era cosa pasada, de la época de su predecesor, Pere de Albalat (1238-1251) (cf. Domínguez Sánchez 1997: 255-256, núm. 126. 
En el caso de la polémica entre Toledo y Compostela, el hecho de que desde 1230 los reinos de Castilla y León se unificaran definitivamente con Fernando III "el Santo», parece que frenó la rivalidad de la Iglesia compostelana con la toledana. ${ }^{117}$ Es probable que el propio monarca intermediase para que finalizasen los conflictos. De hecho, poco después de producida dicha unión, seguramente para apaciguar ánimos y colmar ambiciones, Fernando III ratificó al arzobispo de Compostela en la posesión de la cancillería y de la capellanía regia del Reino de León ${ }^{118}$, lo que le equiparaba en prestigio al de Toledo, que era el titular de la cancillería del Reino de Castilla. Además, como es sabido, durante el reinado de Fernando III el centro de interés de la corona se sitúa en el sur del reino, concretamente en las ciudades de Córdoba y Sevilla, reconquistadas por entonces. La rivalidad se centrará desde ese momento entre las urbes de Toledo y Sevilla. ${ }^{119}$ Por fin, desde mediados del siglo XIII no encontramos más pleitos planteados en la curia romana por compostela sobre la primacía.

\section{DISCIPLINA ECLESIÁSTICA Y CONTROL DE LA VIDA CAPITULAR Y MONÁSTICA}

Canonistas e historiadores han escrito multitud de páginas sobre la legislación conciliar relativa a la regulación y mejora de las costumbres clericales y de la disciplina eclesiástica ${ }^{120}$, definiéndola como el más importante cuerpo de leyes de la Iglesia medieval sobre esta materia. ${ }^{121}$ Las disposiciones en este sentido del Concilio se comenzaron a aplicar pronto en toda la Cristiandad, aunque con particulares dificultades en algunos casos, en especial en los reinos hispánicos. En este sentido hay que resaltar el tenor de un diploma dirigido por Honorio III a los obispos de la provincia toledana en octubre de 1219 , cuatro años tras la finalización del Concilio Lateranense, del que seguramente también se expidieron otros originales para los prelados de las otras provincias hispanas: tarraconense, bracarense y compostelana. ${ }^{122}$ Se trata de un mandato por el que el papa urge a los obispos hispanos a dar cabal cumplimiento a las disposiciones conciliares sobre la vigilancia estricta de la herejía, la observancia de la honestidad y modestia de vida y costumbres de los clérigos, la prohibición de

117 Que se mantuvo a nivel erudito y teórico. Véase Fernández Valverde (ed.) 1987: 273, cap. VIII/10. Todavía en el siglo XVII había defensores de la primacía hispana por parte de la iglesia compostelana. Véase el libro manuscrito de Joseph Bugarín, titulado Historia del Apósto Santiago, único y singular patrón y tutelar de las Hespañas, redactado entre $1650-1660$ y conservado en el Archivo y Biblioteca de la catedral de Santiago de Compostela con las signaturas $\mathrm{M}-15 / 1$ y $\mathrm{M}-15 / 2$, cuyo libro segundo se titula "Libro Segundo en que se demuestran las verdades del libro Primero y cómo Santiago instituyó la Iglesia Iriense su único Obispado y el Primado de España, y los discípulos que allí convirtió» (cf. Sánchez Sánchez 2009: 181-183, núm. 61.

118 Con fecha 25 de enero de 1231. Cf. López Ferreiro 1898-1911, V: Apénd., 55-56, núm. 18.

119 Cf. Herbers 2006: 89-91.

120 Según se dispone en los cánones 7, 14-21 y 63-66 de dicho Concilio. Ed. de Hefele y Leclercq 1913: 1335-1336, 1344-1351 y 1383-1385.

121 Cf. Kuttner y García y García 1964: 163.

122 Mansilla Reoyo 1965: 190-192, núm. 246. Sólo se conserva una copia del texto en un manuscrito de la Biblioteca Nacional, pero no el original ni la transcripción del mismo en los Registros Vaticanos. conferir beneficios eclesiásticos a capellanes indignos, y la interdicción de la pluralidad de beneficios curados, tanto catedralicios como parroquiales:

(...) Quocirca universitati vestre, per apostolica scripta, mandamus et districte precipimus, quatinus preteritam negligentiam (ecclesiasticam) novo studio redimentes, per sollicitudinem germinatam sic prefati statuta Concilii, et illa presertim que salutem respiciunt animarum, deinceps conservetis et faciatis a vestris subditis inviolabiliter observari (...) Invigilantis autem propensius ad hereticam pravitatem de vestris finibus, si forsan irreperit, plenitus extirpandam (...) Ponat etiam unusquisque gladium super femur (...) qui statutis Concilii vilipensis, morum vel vite abiiciat honestatem, vel non observat in tonsura, vestibus et aliis modestiam clericalem; precaventes sollicite ne beneficia conferatis indignis, nec quemquam permitattis habere plures personatus seu parochiales ecclesias habitas post Concilium Generale quibus sit cura animarum annexa (...)

Por lo que se refiere al control de la vida capitular y monástica, baste recordar que dichas disposiciones fueron tenidas en cuenta durante todo el siglo XIII, a veces para cumplirlas y muchas otras veces, desgraciadamente, para solicitar a la curia romana una dispensa de las mismas. ${ }^{123}$

En este sentido, uno de temas más espinosos fue la prohibición conciliar de acumulación de varios beneficios curados. Los papas de la primera mitad del siglo XIII se debatieron en una difícil disyuntiva: mantener en vigor esta disposición o conceder dispensa de la misma. Como es sabido, desde la segunda mitad de dicha centuria son mucho más frecuentes las exenciones de la regla que el cumplimiento de la misma. ${ }^{124}$

Véanse algunos ejemplos de ambas situaciones: En 1236 Gregorio IX comunicaba al electo de Lisboa, Estêvão Gomes, que la audiencia romana trataría las acusaciones existentes contra él por haber acaparado en el pasado diversos beneficios, en contra de la norma del Concilio de Letrán. ${ }^{125}$ En 1267 Clemente IV anulaba la elección capitular de Juan Alfonso, que era nada menos que hijo natural del rey Alfonso IX de León, como arzobispo de Compostela, basándose en que a lo largo de su carrera eclesiástica había ido acumulando numerosas prebendas, desobedeciendo los mandatos conciliares y sin la pertinente licencia papal. ${ }^{126}$

Por contra, ya en 1231 Gregorio IX concedía al deán de Compostela, Juan Galván, facultad para retener legítimamente su deanato junto con otros dos beneficios. ${ }^{127}$ De igual modo, en 1238 concedía a Arias Pérez, canónigo

123 La cláusula derogativa "constitutione Generalis Concilii super pluralitate beneficiorum edita non obstante» se repite cientos de veces en la documentación pontificia del siglo XIII.

124 Es muy elocuente a este respecto el preámbulo de unas litterae gratiosae de Honorio IV, dadas en 1285, por las que permitía a Domingos, arcediano de Lisboa y canónigo de Coímbra, aceptar un nuevo beneficio curado: «Etsi propter ambitiones quorumdam ne quis plures ecclesias vel ecclesiasticas dignitates habeat Sacri Concilii constitutio interdicat, Apostolice tamen Sedis benignitas provide pensans merita singulorum, illos nonumquam gratia prosequitur ampliori, quos vite laudabilis litterarum scientia et morum honestas decorant». Ed. Domínguez Sánchez 2015: 54.

125 Cf. Domínguez Sánchez 2004: 450-451, núm. 554.

126 Cf. Domínguez Sánchez 1996: 275-278, núm. 153.

127 Cf. Domínguez Sánchez 2004: 183, núm. 174. 
de Orense, una gracia similar. ${ }^{128}$ Sin embargo, en algunas ocasiones dicha dispensa estaba condicionada al nombramiento de un vicario que, en alguna de las iglesias, atendiese a las almas. Así, en 1239 Gregorio IX facultaba al clérigo Bavalo para poseer dos canonjías, una en Coria y otra en Salamanca, pero con el compromiso de designar un capellán que atendiera la cura de almas en la catedral salmantina. ${ }^{129}$

Además, hay que recordar que en el Concilio se reguló con detenimiento la forma de elección y nombramiento de prelados, beneficiados y prebendados, ${ }^{130}$ con unas normas de procedimiento que estuvieron en vigor durante mucho tiempo. En 1220 Honorio III actuaba nada menos que contra el arzobispo de Toledo por haber designado prebendado de su catedral a un capellán personal, sin tener en cuenta las disposiciones conciliares que regulaban tales nombramientos capitulares. ${ }^{131}$

Del mismo modo, nueve años más tarde, en 1229, Gregorio IX anulaba la elección capitular del propio metropolitano de Braga, por no haber seguido las pautas canónicas aprobadas en el Concilio de Letrán. ${ }^{132}$ Igualmente, este mismo pontífice llamaba al orden en 1234 al arzobispo de Compostela, Bernardo, por haber designado de manera irregular, en contra los decretos conciliares, al obispo de Lisboa. ${ }^{133}$

Por lo que se refiere a la vida monástica, es sabido que el Concilio ordenó la celebración de asambleas y sínodos locales para las órdenes monásticas ${ }^{134}$, en especial para la Benedictina, cuya reforma se exigía. Honorio III recordó en 1219 a los benedictinos hispanos que, de acuerdo con dicho mandato del Concilio Lateranense, debían celebrar de forma inmediata concilios provinciales ${ }^{135}$ :

Abbates vero nigri Ordinis celebrare hoc anno provincialia concilia non omittant, prout extitit in prescripto Concilio stabilitum (...)

Como ya se ha indicado, diversos papas del siglo XIII trataron de imponer en la península ibérica, a través de sus legados, las decisiones tomadas en el Concilio IV de Letrán, destacando entre todos, a este efecto, la inmensa labor del cardenal legado Jean Halgrin de Abbeville. ${ }^{136}$ Es muy expresivo, a este respecto, el inicio de una carta del citado

128 Cf. ibídem: 581, núm. 738.

129 Cf. ibídem: 649, núm. 829. Lo mismo hizo ese año con Fernando Alfonso, arcediano de Oviedo (cf. ibídem: 671, núm. 848).

130 Cánones 23 a 26 del Concilio, donde se regula el procedimiento de elección de los mismos y se proscribe la intervención laica en dicha elección. Ed. de Hefele y Leclercq 1913: 1352-1356.

131 Cf. Hernández 1996: 543, núm. 681.

132 Cf. Domínguez Sánchez 2004: 135-136, núm. 113. Véase este revelador párrafo: "Sane ecclesia Bracharensi pastore vacante, capitulum eiusdem in te (Silvestrem), tunc Bracharensem decanum, qui preesse poterat et prodesse, vota sua unanimiter direxerunt, set, quia processum qui a dicto capitulo super ipsius electione habitus fuerat inordinatum invenimus, cum scrutinium non fuerit redactum in scriptis et ante electionem consensus eiusdem extiterat requisitus, quod super hoc factum extitit tamquam contra Generalis formam Concilii attemptatum, iustitia cassavimus exigente, provisione nobis ipsius ecclesie reservata».

133 Cf. ibídem: 349-350, núm. 408.

134 Canon 12. Ed. de Hefele y Leclercq 1913: 1342-1344.

135 Mansilla Reoyo 1965: 190-192, núm. 246.

136 Véase un excelente resumen tanto de su labor como de las reacciones contrarias a ésta en Linehan 1975: 17-29. legado, expedida en Valladolid a fines del año 1228, en presencia de los obispos de los reinos de Castilla y de León, cuyo texto únicamente conocemos por una traducción al castellano hecha en el siglo XV, que dice lo siguiente ${ }^{137}$ :

Éstas son las constituciones que mestre lohán, cardenal de Sabina e legado en Espanna, fizo en Valladolit, presentes todos los prelados de Castiella e de León, que fueron fechas era de mill e dozientos e LXVI annos: Nos, queriendo, con otorgamiento destos presentes padres, acorrer a las enfermedades e a los periglos de las almas que vienen por non aguardar las sanctas constituciones, mandamos que daquí endelante, con mayor diligencia, sean aguardados los establescemientos del sancto Concilio General, los quales en gran partida, non sien grave periglo, son despreciados, e que sean castigadas afincadamente todas aquellas cosas que locamiente son fechas contra este mismo Concilio (...)

Como es bien sabido, el cardenal de Abbeville recorrió en año y medio prácticamente todas las Iglesias hispanas ${ }^{138}$ tratando de imponer los acuerdos conciliares, y muy especialmente en el aspecto que ahora se está tocando: el de la disciplina eclesiástica. Ahora nos es imposible detenernos en cada una de las disposiciones que él dictó, pero sí es interesante comentar un poco más su citada carta del año 1228, porque viene a ser como un resumen de las medidas que él recordó en cada lugar que visitó, en la cual aludía a los siguientes aspectos a su juicio esenciales que deberán guardar:

- Celebración anual o semestral de concilios por provincias eclesiásticas y de sínodos diocesanos. ${ }^{139}$ Adecuada ordenación parroquial de las diócesis.

- Establecimiento en cada catedral y convento de maestros letrados, debidamente pagados. ${ }^{140}$ Obligación para todos los clérigos de estudiar Latín y Gramática. ${ }^{141}$

- Castigo ejemplar, severo e irrenunciable a los clérigos concubinarios.

137 Cf. Domínguez Sánchez 2004: 107-110, núm. 85.

138 Visitó y/o expidió diplomas para las iglesias y/o colegiatas de Compostela, Lugo, Astorga, León, Oviedo, Zamora, Salamanca, Braga, Guimarães, Coímbra, Oporto, Ávila, Burgos, Cuenca, Segovia, Calahorra-La Calzada, Palencia, Valladolid, Toledo, Sigüenza, Osma, Zaragoza, Tarazona, Tudela, Huesca, Lérida, Calatayud, Urgell, Tarragona, Barcelona, Gerona, Vic, etc.

139 Según establecía el canon 6 del Concilio IV Lateranense. Ed. de Hefele y Leclercq 1913: 1334-1335.

140 De acuerdo con lo establecido en los cánones 11 y 27 del Concilio IV de Letrán, donde se reafirma que la ignorancia es el origen del error. Ed. de ibídem: 1341-1342 y 1356.

141 Es muy elocuente el siguiente texto de una carta del citado legado, despachada en marzo de 1229 , por la que promulgaba solemnemente los estatutos aprobados en un concilio celebrado en Lérida para regularizar la disciplina eclesiástica en la provincia de Tarragona: "Cum in Generali Concilio pia fuerit constitutione provisum ut non solum in cathedralibus ecclesiis, sed etiam in aliis, in quibus suppetunt facultates, magistris, qui ibidem laborant in doctrina, provideatur in beneficio compententi, nos, attendentes quod in partibus Hispanie ex defectu studiorum et literature multa et intolerabilia detrimenta animarum proveniant, non solum in locis statutis predictam constitutionem precipimus observari, verum etiam ad multiplicem ignorantiam extirpandam eatenus scholas multiplicari statuimus, ut per singulas dioceses in quolibet archidiaconatu in certis locis, si ad hec loca idonea inventa fuerint, per provisionem episcopi schole de Grammatica statuantur et magistri collocentur». Cf. Domínguez Sánchez 2004: 119-124, núm. 99. 
- Moderación en el uso de vestiduras lujosas para los clérigos, y prohibición de uso de armas para ellos. ${ }^{142}$

- Custodia apropiada de cálices, corporales, pilas bautismales y vestiduras sacramentales.

- Veto a la pluralidad de beneficios eclesiásticos. Revalorización de los beneficios individuales. Obligación de residencia en los beneficios curados. Veto a la subdivisión de las prebendas. Prescripción a los cabildos ${ }^{143}$ para que ajustaran el número de sus miembros a la cuantía de sus rentas. ${ }^{144}$

- Regulación de los estipendios ${ }^{145}$ recibidos por los prelados y párrocos. ${ }^{146}$

- Respeto a la jurisdicción episcopal sobre la provisión de los beneficios eclesiásticos. Veto al abuso por parte de algunos laicos en sus derechos patronales sobre determinados beneficios. ${ }^{147}$

- Prohibición de la venta de los bienes monásticos. Obligación de los monjes de guardar sus votos, en especial el de pobreza. Reunión trianual de capítulos monásticos. ${ }^{148}$

- Castigo severísimo a los clérigos prendidos «en furto, en robo, en omecidio, en robo de mugieres o faciendo falsa moneda».

- Cuidado esmerado en la cura de almas. Los clérigos deberán recordar a todos los fieles su obligación de recibir la confesión y comunión anuales.

Veremos únicamente, en este sentido, las medidas tomadas al respecto en la diócesis y provincia de Compostela: El arzobispo de Santiago había logrado de Honorio III, en $1219^{149}$, la exención de la obligación de reunirse en concilio anualmente, teniendo en cuenta la dispersión y lejanía entre sus obispados, aplazando dichas asambleas para períodos trianuales. Esta dispensa seguramente tenía que ver con una anterior protesta formal elevada contra la convocatoria en 1217 de un sínodo por el arzobispo compostelano, Pedro Muñiz, en el que se adoptaron diversas medidas contra los abusos morales del clero, y en el que los eclesiásticos de las sedes del sur de la provincia compostelana, concretamente de las diócesis de Zamora, Ávila, Plasencia, Coria, Ciudad Rodrigo y Salamanca, se quejaban de que no se les había consultado

142 En 1232 el obispo electo de León es acusado de no acatar los preceptos del Concilio por usar túnica de manga larga y, para montar a caballo, silla, freno, armadura y espuelas lujosamente dorados, motivo por el que se pide que no sea confirmado para dicha mitra. Cf. ibídem: 224-225, núm. 227.

143 Sobre el cabildo de Santiago de Compostela, cuyo dominio se extendía por amplias zonas de León, Galicia y Portugal, y sobre sus rentas, véase el excelente estudio de Pérez Rodríguez 1994: 169-201.

144 Todo ello porque el legado Abbeville estaba convencido de que la reforma moral estaba ligada a la reorganización económica.

145 Según los cánones conciliares 32-34. Ed. de Hefele y Leclercq 1913: 1359-1361.

146 Como ejemplo, en 1236 Gregorio IX, de acuerdo con lo aprobado en el Concilio, prohibía a cualquier obispo o arcediano cobrar «procuraciones» a las iglesias del coto monástico de Sahagún, si no las visitaba personalmente. Cf. Domínguez Sánchez 2004: 454-455, núm. 559.

147 Véanse los cánones 32 y 43-46 del Concilio. Ed. de Hefele, y Leclercq 1913: 1359-1360 y 1366-1369.

148 De acuerdo con el canon 12 del Concilio. Ed. de ibídem: 1342-1344.

149 Cf. López Ferreiro 1898-1911, V: Apénd., 33, núm. 11; y González Balasch 2004: 523-524, núm. 278. para la realización del mismo. ${ }^{150}$ Esta queja es sintomática de las reticencias del clero hispano, también del afincado en la región noroeste de la península, a acatar las duras reformas conciliares en cuestiones de moral, orden y decoro. ${ }^{151}$

Pero no por ello dejaron de reunirse en Compostela asambleas eclesiásticas, en las que paulatinamente se fueron aprobando para estos territorios las normas de disciplina eclesiástica comentadas más arriba; más aún tras la visita a la ciudad de Santiago, en noviembre de 1228 del citado cardenal Abbeville. ${ }^{152}$ Desde 1229 y hasta mediados de siglo, en efecto, se celebraron en dicha ciudad al menos dos sínodos diocesanos y un concilio provincial. ${ }^{153}$ En fin, visto esto, se entienden claramente estas palabras de Peter Linehan: "La llave maestra del programa de reforma dell cardenal) Juan fue la institución de los concilios provinciales y de los sínodos diocesanos, ya que únicamente a fuerza de constantes presiones desde arriba es como se podía conseguir que el clero aceptara el nuevo sistema de vida». ${ }^{154}$

La implantación de dichas normas en otras diócesis del noroeste hispano se llevó a cabo de manera semejante al modo que se ha visto en Compostela, con dificultades y paciencia, a través de sínodos y en especial gracias a la influencia del legado Abbeville. Sabemos de la existencia de cartas de este cardenal, expedidas entre los años 1228 y 1229 , sobre la reforma eclesiástica, dirigidas a las iglesias de Astorga, León, Oviedo, Zamora, Salamanca, Lugo, Guimarães, Coímbra, Braga, Oporto y Ávila. ${ }^{155}$ A este respecto, hay que resaltar en especial las constituciones aprobadas en el citado Concilio de Valladolid, celebrado entre los meses de septiembre y diciembre de 1228 , presidido por el legado papal Abbeville, y en el que estuvieron presentes «todos los prelados de los reinos de Castilla y León ${ }^{156}$, y los decretos, hoy por desgracia desaparecidos, aprobados en el Concilio de Salamanca, reunido en esta ciudad en los primeros días de febrero de 1229, en el que estuvieron presentes los obispos del Reino de León. ${ }^{157}$ Además, aunque con fecha desconocida, parece seguro que el legado Abbeville reunión ${ }^{158}$ por entonces un capítulo general monástico en el Reino de León. ${ }^{159}$

150 Cf. Pressutti 1888, I: núm. 623.

151 Sobre las reacciones hispanas a las prescripciones del legado Jean de Abbeville, véase el texto de Linehan 1975: 31-47.

152 Cf. López Ferreiro 1898-1911, V: 135, donde, el 3-XI-1228, suscribió un diploma en el que decía «... dum essemus in Compostellana ecclesia, ipsam ex legationis officio visitantes...».

153 Cf. ibídem, V: Apénd., 49-52, núm. 16; 71-74, núm. 28; y 75-81, núm. 29. De todas maneras, como demuestra Linehan, en algunos de estos sínodos se pasaron por alto algunos de los mandatos del cardenal Abbeville (cf. Linehan 1975: 32-33).

154 ibídem: 28.

$155 \mathrm{Y}$, en general, en todas las sedes de la mitad norte de la península visitadas por el citado legado. Cf. Domínguez Sánchez 2004: núms. 43, 61, 62, 69, 75-77, 80, 85, 87-90, 93, 94, 97, 99, 100, 102, 103, 107, $110,111,115,125,127-133,136,138,144,147,162,166,167,174,183$, $185,188-190,200,208,220,257,264,282,336,388,412,453,490-492$, $508,570,602,657,689,690$ y 858 .

156 Cf. ibídem: 107-110, núm. 85.

157 Cf. López Ferreiro 1898-1911, V: Apénd., 46-47, núm. 15; y González 1944.

158 Cuyas actas publicaron Martène y Durand 1717: 167 y ss.; tomándolas de ellos Mansi 1778: 1090-1094.

159 Tampoco podemos ahora detenernos en la «suavización» de las drásticas medidas dictadas por el cardenal Abbeville (en ocasiones contraproductivas) que tuvo lugar en época de Inocencio IV (1243-1254). Cf. al respecto Linehan 1975: 44-47. 


\section{DISPOSICIONES PARA MEJORAR LA VIDA DE PIEDAD DE LOS FIELES}

Entre los temas más conocidos tratados en el Concilio están los relativos al cuidado de la vida cristiana y sacramental de los fieles. ${ }^{160}$ Como se sabe, en este Concilio se proclamaron medidas dogmáticas para evitar los errores de la herejía albigense, y se estableció por vez primera y de manera disciplinar el precepto de la confesión y comunión pascual, en especial tras proclamar solemnemente la transubstanciación eucarística. Los legados papales trataron en los años posteriores de que tales medidas se pusiesen en efecto de forma inmediata en toda la Cristiandad. Así, en 1228 el cardenal legado Jean Halgrin de Abbeville mandaba a los obispos del noroeste hispano lo siguiente: ${ }^{161}$

Item, stablecemos e mandamos que los clérigos de Missa amonesten a su pueblo que se vengan a confessar, aguardando la constitución del Concilio General, conviene a saber, que se alguno non se confessar nin comulgar una vez en el anno al menos, en la vida non entre en la eglesia, en la muerte non sea soterrado.

En el Concilio se expusieron claramente los errores cátaros acerca de la Iglesia y los sacramentos de la Eucaristía, bautismo y matrimonio. Del mismo modo, se aprobaron normas para elevar la moralidad profesional y comercial. ${ }^{162}$ Pero estas disposiciones teóricas calaron en el pueblo cristiano más que por estar plasmadas en cánones conciliares, por la difusión de las mismas que harían pronto las nacientes órdenes mendicantes, de franciscanos y dominicos, cuya prodigiosa expansión por toda Europa, también por el noroeste hispano, comenzó precisamente desde 1215.

Por otro lado, el Concilio prohibió prácticas corrientes que atentaban contra la moral cristiana, entre ellas el ejercicio de la usura. ${ }^{163}$ Esta decisión se puso en práctica en numerosas ocasiones a lo largo del siglo XIII. Así, recordando las disposiciones conciliares, en 1237 Gregorio IX inició un juicio contra diversos laicos de León acusados de cobrar intereses (excesivos) en sus negocios ${ }^{164}$; y al año siguiente, en 1238 , obligó a que se le devolviesen al noble leonés Pedro Ponce de la Valdería diversas cantidades que otros caballeros le habían sustraído con usura. ${ }^{165}$

\section{REGULACIÓN EXPRESA DEL SACRAMENTO DEL MATRIMONIO}

Otro de los puntos muy señalados de entre los aprobados en el Concilio es el relativo a la regulación del sacramento del matrimonio: en especial, la prohibición de los matrimonios clandestinos ${ }^{166}$ y el veto expreso, salvo con dispensa papal, a la unión de personas con tercer y cuarto grado de parentesco. ${ }^{167}$ Desde el mismo momento en que

160 Cánones 20 y 21 del Concilio. Ed. de Hefele y Leclercq 1913: 1349-1351.

161 Cf. Domínguez Sánchez 2004: 107-110, núm. 85.

162 Cánones 22 y 23 del Concilio. Ed. de Hefele y Leclercq 1913 1351-1352.

163 Canon 67 del Concilio. Ed. de ibídem: 1385-1386.

164 Cf. Domínguez Sánchez 2004: 529, núm. 661.

165 Cf. ibídem: 598-599, núm. 762.

166 Canon 51 del Concilio. Ed. de Hefele y Leclercq 1913: 1373-1374.

167 Cánones 50 y 52 del Concilio. Ed. de ibídem: 1372-1375. finalizó en concilio la petición de dichas dispensas fue muy elevada, casi en tanta medida como las cartas papales recordando la obligación de cumplir dicho precepto.

Así, en 1229 Gregorio IX recordaba a su legado en España, el cardenal de Abbeville, que pusiera orden en la península en relación con varios temas, en especial con el matrimonial, vetando las uniones inválidas. ${ }^{168}$

De hecho, en ocasiones ni la monarquía se libraba del estricto cumplimiento de tal requisito: así, en ese mismo año 1229 el papa mandaba al citado legado que anulase el matrimonio del rey de Aragón, Jaime I, con la infante Leonor de Castilla ${ }^{169}$, aduciendo que «Cum Generale Concilium inhibitione copule coniugalis in tribus ultimis gradibus revocata (...)». Y recuérdese el grave conflicto suscitado en el reino Castilla y León, a fines del siglo XIII y principios del XIV, ante la negativa de Nicolás IV para aceptar el matrimonio entre Sancho IV y María de Molina, parientes en tercer grado. ${ }^{170}$

Sin embargo, los casos de dispensa papal de tal impedimento son múltiples, especialmente desde fines del siglo XIII, y no sólo de reyes y nobles, sino de todo tipo de solicitantes. Véase un único ejemplo: en 1290 el recién citado Nicolás IV relevaba de tal dificultad canónica a un matrimonio de la ciudad de Oviedo, formado por Rodrigo Martínez y Elvira Rodríguez, del que no se tiene otro dato alguno en ningún tipo de fuente escrita, lo cual es suficiente prueba de su sencilla condición social. ${ }^{171}$

\section{MEDIDAS TOMADAS CON RELACIÓN A LOS JUdíOS}

Como es bien conocido, el Concilio IV de Letrán dictaminó polémicas medidas con respecto a los judíos que vivían en los reinos cristianos, por las cuales se les obligaba principalmente a pagar ciertos diezmos (por las propiedades adquiridas a los cristianos) y a llevar señales distintivas de su condición. ${ }^{172}$ Además, se decretó que se abstuvieran de usuras inmoderadas y de atacar a los clérigos, se les obligó a responder en juicio eclesiástico por sus excesos y, además, se les exigió que estableciesen sus cementerios lejos de los camposantos cristianos. ${ }^{173}$ La aplicación de estas medidas fue numerosas veces reiterada por los pontífices del siglo XIII, lo cual es buena prueba de que no se cumplieron siempre ni en todos los lugares.

Honorio III mandará en 1218 y 1219 observar en toda la península ibérica los decretos del Concilio de Letrán sobre los referidos hebreos. ${ }^{174}$ Sin embargo, el canon conciliar relativo a la obligación de los judíos de vestir de manera diferente a los cristianos no era bien visto por todos, comenzando por los reyes hispanos: de hecho, el rey de Castilla, Fernando III, en ese mismo año 1219 solicitó al papa suspender por un tiempo dicha disposición, alegando que «las

\footnotetext{
168 Cf. Domínguez Sánchez 2004: 111-112, núm. 87.

169 Cf. ibídem: 112-113, núm. 89.

170 Cf. Domínguez Sánchez 2009: 258-259, núm. 236.

171 Cf. Domínguez Sánchez 2009: 296-297, núm. 279.

172 Cánones 68 y 69 del Concilio. Ed. de Hefele y Leclercq 1913: 1386-1388

173 Véase Domínguez Sánchez 2004: 117, núm. 97.

174 Cf. Hernández 1996: 539, núm. 669; y 542, núm. 678. Dirigido al arzobispo de Toledo en su calidad de legado papal, por lo cual afectaba a toda la península ibérica.
} 
rentas reales en gran parte se mantenían gracias a dichos judíos», petición a la cual accedió el pontífice. ${ }^{175}$ Lo mismo ocurrió en Aragón, en 1220, a petición del rey Jaime $\mathrm{I}^{176}$, que afirmaba que, por culpa de tal norma, los judíos aragoneses abandonaban su reino. En 1231 Gregorio IX recordaba a Sancho II de Portugal que los «iudei in episcopatu Ulixbonensi publicis passim preferuntur officiis, contra statuta Concilii Generalis, in obprobium fidei christiane et grave scandalum plurimorum». ${ }^{177}$ Además, en 1233, Gregorio IX reiteraba a Sancho VII de Navarra que debía obligar a sus súbditos a cumplir la normativa conciliar que obligaba a distinguir a judíos de cristianos por su indumentaria. ${ }^{178}$ Sabemos que entre las disposiciones del relevante citado Concilio «legatino» de Valladolid, que reunió a los prelados de los reinos de León y de Castilla, no se decretó el uso de vestimentas especiales por parte de los judíos.

Las órdenes papales para exigir el cumplimiento de las normas relativas a los hebreos fueron, como decíamos, muy frecuentes durante el siglo XIII en todos los reinos hispanos, también en la zona geográfica noroeste peninsular. Véase sólo un ejemplo: en 1233 el pontífice comisionó al arzobispo Bernardo de Compostela, y a todos sus sufragáneos, para que se ocupasen de que los "insolentes" judíos viviesen separados de los cristianos, con las siguientes y elocuentes palabras $^{179}$ :

Sicut enim nostris fuit auribus intimatum, iudei in Ispania existentes facti sunt adeo insolentes, ut illos excessus committere non pavescant, quod sustineri eos a Christi fidelibus non solum indignum est, set etiam inhumanum; nam licet in Generali Concilio provida fuerit deliberatione provisum ut tales utriusque sexus in omni christianorum provincia et omni tempore qualitate habitus publice ab aliis populis distinguantur, id tamen in Ispaniarum partibus, ut dicitur, non servatur, propter quod verendum est ne illorum isti vel istorum illi mulieribus dampnabiliter misceantur (...)

\section{LLAMAMIENTO A LA CRUZADA}

Quizá el asunto más tratado por los historiadores en relación con las decisiones del Concilio IV Lateranense es el relativo a la promoción de la Quinta Cruzada contra los musulmanes de Oriente, a la que se llamó a participar a todos los católicos. ${ }^{180}$

Es sabido que el canon 54 del Concilio ${ }^{181}$ había dispuesto que todos los eclesiásticos de la Cristiandad pagasen la «vigésima» durante tres años, con destino a la mencionada Cruzada. Como era de esperar, ello originó pronto protestas, reclamaciones y aclaraciones por parte de diversos clérigos ibéricos, también del noroeste hispano ${ }^{182}$, a quienes les parecía fuera de lugar que se les exigiera a contribuir en una

\footnotetext{
175 Cf. ibídem: 542, núm. 679; y Mansilla Reoyo 1965: 164, núm.

176 Cf. ibídem: 236, núm. 317.

177 Cf. Domínguez Sánchez 2004: 202-204, núm. 203.

178 Cf. ibídem: 267, núm. 294.

179 Cf. ibídem: 273-274, núm. 303.

180 Véase el texto aprobado en el Concilio y un análisis del mismo en: Hefele, y Leclercq 1913: 1388-1395.

181 Cf. Mansi 1778: 1042 y ss.; y Hefele y Leclercq 1913: 1390-1395.

182 Manifestaron sus quejas en la primera mitad del siglo Lucas Tudense y en la segunda mitad Juan Gil de Zamora. Cf. Linehan 1975:
} 212. 5-6. lucha contra los musulmanes fuera de sus fronteras, cuando tenían al enemigo "en casa». $Y$ es que los eclesiásticos hispanos tenían muy en cuenta los enormes esfuerzos económicos que habían tenido que prestar en la lucha contra los almohades, tal como antes se indicó. Por ello, utilizaron todo tipo de tácticas dilatorias para no pagar dicha contribución, con el consiguiente enfado del papado. Pasados cuatro meses del plazo indicado para que los eclesiásticos contribuyesen con la "vigésima», esto es, en diciembre de 1216, no se había recaudado nada, a pesar de las continuas idas y venidas de los colectores pontificios (Hospitalarios y Templarios). Por entonces Honorio III $^{183}$ contestó agriamente a varias consultas sobre el tributo le había propuesto el cabildo de Compostela ${ }^{184}$, recordando que

(...) cum Generalis Concilii fuerit approbatione statutum ut omnes omnino clerici, tam subditi quam prelati, vicessimam ecclesiasticorum proventuum usque ad triennium conferant in subsidium Tere Sancte (...)

Como agudamente ha puesto de manifiesto el profesor Linehan, fue el propio arzobispo de Toledo quien se encargó por aquellos años 1216-1220 de usar numerosos engaños, rapiñas y fraudes para evitar el pago de la "vigésima". ${ }^{185}$ Por otra parte, hay que recordar que los reyes hispanos finalmente no acudieron en persona a las cruzadas a Tierra Santa, salvo una rara excepción tardía en la casa regia navarra. ${ }^{186}$

Finalmente, desde la tercera década del siglo XIII, los pontífices romanos, teniendo en cuenta la particular situación de la península ibérica, comenzaron a favorecer y a conceder indulgencias a los hispanos que luchasen contra los musulmanes presentes al sur de dicha península, de tal manera que la Reconquista hispana quedaba equiparada a la Cruzada a Tierra Santa, tal como expresaban los propios diplomas ${ }^{187}$ :

(...) Sane gaudemus in Domino et in Eius laudibus delectamur quod in partibus Ispanie prosequens causam suam fugavit et fugat a facie fidelium sarracenos, ut cultus divini nominis amplietur, et semen Ecclesie gentes hereditet, et desertas inhabitet civitates. Verum, quia necesse est in partibus illis quasi iuguem continuari succursum ad retinendas terras noviter acquisitas, et alias acquirendas, ut exercitatis in eo sit causa salutis eterne; (...) universitatem vestram rogamus (...) quatinus illuc universi et singuli succurratis, ut per hec et alia bona que, Domino inspirante, feceritis, incomparabilem vobis gloriam et gratiam comparetis (...)

Esta disposición también afectó en los años siguientes al noroeste hispano. Así, en octubre de 1230 Gregorio IX otorgó a todos los fieles del Reino de León que combatiesen

\footnotetext{
183 Ed. Mansilla Reoyo 1965: 13-14, núm. 16.

184 Sobre los aspectos económicos del cabildo compostelano, cf. Pérez Rodríguez 1994.

185 Cf. Linehan 1975: 6-16.

186 Gregorio IX solicitó en 1238 un subsidio eclesiástico a los prelados del reino de Navarra porque Teobaldo I pretendía embarcarse hacia los Santos Lugares. En efecto, el rey navarro dirigió un ejército cruzado a Tierra Santa en aquel año, y, a pesar de ser derrotado, debido a los enfrentamientos entre los musulmanes, obtuvo para los cristianos Jerusalén, Belén y Ascalón, retornando a Navarra en 1240. Cf. Domínguez Sánchez 2004: 620, núm. 789.
}

187 Cf. ibídem: 347-348, núm. 405, con fecha de 21-X-1234. 
contra los sarracenos por un período de cuatro años las mismas gracias espirituales que tenían quienes se alistaban para la conquista de los Santos Lugares. ${ }^{188}$ En octubre de 1234 este mismo pontífice concedía una merced similar a los que socorriesen al rey de Portugal, Sancho II, en su lucha con musulmanes. ${ }^{189}$ Algo después, en 1236, Gregorio IX mandaba al arzobispo de Compostela y a los obispos del Reino de León que concediesen a los repobladores de la recién conquistada de Córdoba la indulgencia conciliar para los cruzados. ${ }^{190}$

Por otro lado, el Concilio también había aprobado que los obispos locales pudiesen solicitar un «moderado subsidio" a los clérigos y laicos de su diócesis, si había causas manifiestas y razonables para ello, entre las que estaban los gastos de la guerra contra los musulmanes. Los prelados hispanos se acogieron a esta norma para financiar las luchas que mantenían con los sarracenos. Así, en 1225 Honorio III mandaba a los eclesiásticos y fieles de Palencia que ayudasen con sus bienes a su obispo, Tello Téllez de Meneses, empeñado en la lucha contra los almohades, de forma que «ille, vobis ei pie cooperantibus, prosecutioni negotii Ihesu Christi efficacius possit insistere». ${ }^{191}$

Por otra parte, el Concilio favoreció la labor de las Órdenes Militares contra los musulmanes. De hecho, amparándose en ello, unos años más tarde, en 1227, Gregorio IX ordenó a todos los obispos del Reino de León que respaldasen a la Orden de San Julián del Pereiro, castigando a quienes se apoderasen de sus bienes. ${ }^{192}$

Además, tal como se conoce perfectamente, en el Concilio IV de Letrán se había dispuesto que todos los reyes cristianos enfrentados entre sí firmasen una tregua por cuatro años, a fin de favorecer el éxito de la nueva Cruzada que se proyectaba. ${ }^{193}$ Una vez retornados a sus lugares de origen, los prelados asistentes al Concilio amonestaron a los reyes de León, Alfonso IX, y de Castilla, Enrique I, para que cumpliesen este acuerdo conciliar, pues estos reinos contendían desde tiempo atrás por desacuerdos territoriales y de sucesión. Ambos llegaron a un tratado de paz en 1216, que enviaron al pontificado para su ratificación ${ }^{194}$, cuyo preámbulo es significativo:

Cum per veridicam episcoporum nostrorum aliorumque qui vestro Sacro interfuere Concilio relationem certissime didicerimus, quod Vestra Sanctitas, prudenter providens succursui Terre Sancte firmiter constituerit, ut inter omnes catholicos firma pax vel treuga per totum sequens quadriennium observetur (...)

188 Cf. ibídem: 170, núm. 155.

189 Cf. ibídem: 347-348, núm. 405. Dice literalmente: «omnibus cum rege (Portugalie) predicto vel exercitu suo personaliter illuc proficiscentibus contra eos (sarracenos), illam remissionem peccaminum indulgemus que succurrentibus Terre Sancte concessa est in Concilio Generali; presentibus post quadriennium minime valituris». Poco después, en 1239 , concedió el papa numerosas mercedes a quienes colaborasen en la lucha contra los sarracenos del Algarbe iniciada por Fernando Infante de Serpa, hijo del rey Alfonso II de Portugal (cf. ibídem: 688-695, docs. núms. 875-884).

190 Cf. ibídem: 477-478, núm. 591.

191 Cf. Mansilla Reoyo 1965: 440-441, núm. 586.

192 Cf. Domínguez Sánchez 2004: 61-62, núm. 22. Lo mismo hizo con la Orden de Calatrava para toda la península, cf. ibídem: 63, núm. 25.

193 Cf. Mansi 1778: 1012 y ss.

194 Ed. por Mansilla Reoyo 1955: 583-584, núm. 566, con fecha de 12-VIII-[1216]. Véase el comentario de López Ferreiro 1898-1911, V: 70-71.
Del mismo modo, en abril de 1216, Inocencio III comisionaba al obispo de Burgos y al deán de Compostela para que exigiesen a Alfonso II de Portugal que firmase la paz con sus hermanas, Teresa y Sancha, a las que les había arrebatado los castillos de Montemaior y Alenquer. ${ }^{195}$ Lo mismo hizo en los años inmediatamente posteriores Honorio III. Así, a principios del año 1218 comisionó al arzobispo de Toledo para que se ocupase de que todos los reyes y príncipes hispanos observasen la paz decretada en el Concilio de Letrán. ${ }^{196}$

Para concluir, aunque este artículo se ha centrado sobre todo en recoger críticamente la mucha información existente sobre este tema, heurística y bibliográfica, muy amplia pero dispersa y desordenada, debemos recapitular a y ahondar en algunos aspectos interpretativos de la cuestión. Y en primer lugar hay que señalar que, aunque a veces con aciertos y otras con errores, con presteza o con retraso, con luchas y con titubeos entre su aceptación o su rechazo, las medidas tomadas en el IV Concilio de Letrán, tanto en aspectos religiosos como en otros sociales e incluso políticos y económicos, acabaron implantándose en el noroeste hispano.

Las pretensiones de Inocencio III en la citada bula de convocatoria del Concilio, «ad extirpanda vitia et plantandas virtutes, corrigendos excessus et reformandos mores, eliminandas hereses et roborandam fidem, sopiendas discordias et stabiliendam pacem, comprimendas oppressiones et libertatem fovendam, inducendos principes et populos christianos ad succursum et subsidium Terre Sancte», acabaron paulatinamente, aunque también parcialmente, por cumplirse. Las miles de dispensas concedidas en los últimos siglos bajomedivales por el papado, en el sentido de excusar a clérigos y laicos del cumplimiento de lo aprobado en el Concilio Lateranense, se pueden interpretar de dos modos: como un olvido de lo acordado en él, pero también como una medida pasajera a favor sólo de determinadas personas privilegiadas, pero que no libraba a la sociedad cristiana de acabar consumando las decisiones conciliares.

Ya citamos a Patrick Henriet ${ }^{197}$, con quien compartimos su tesis de que lo político y lo religioso se entremezclan irremediablemente en la historia. Los intereses y las ambiciones personales de reyes y grandes eclesiásticos compartieron espacio con los intentos de los pontífices y de sus legados de implantar un cambio de rumbo en la Iglesia hispana. Desde el año 1215 el devenir de la Iglesia universal, también de la Iglesia del noroeste hispano, dio un vuelco. Cuestiones sacramentales, matrimoniales y de piedad "cotidiana» se vieron modificadas para siempre. El auge las órdenes mendicantes desde ese momento reforzó estos cambios. Los excesos en cuestiones beneficiales o de rentas eclesiásticas sólo se moderaron en parte, pero se crearía una nueva manera de pensar en este asunto que tres siglos después acabaría irremediablemente estallando. Asuntos terriblemente importantes para la Iglesia ibérica de aquel momento, como el de la primacía, provocaron

195 Ed. por Mansilla Reoyo 1955: 573-575, núm. 549.

196 Ed. por ibídem: 121, núm. 149.

197 Henriet 2004: 296 y ss. 
descomunales discusiones en la curia pontificia, algunas verdaderamente vergonzosas, pero con el paso del tiempo, y también por la intervención de otros poderes, acabaron casi en nada. Otras cuestiones de calado más bien político, como un mayor control de la comunidad judía, o la intervención en Tierra Santa, tuvieron poco eco en el noroeste ibérico, pero a la larga sí tuvieron efecto, porque contribuyeron a aumentar los prejuicios contra los hebreos o a elevar la presión en la Reconquista hispana. En fin, desde 1215 la Iglesia del noroeste hispano, al igual que toda la sociedad, experimentaron una paulatina mudanza y transformación hacia unos tiempos nuevos, hacia lo que los historiadores de hoy conocemos como la Época Bajomedieval.

Las fechas en principio no son más que números, que interesan quizá más a los matemáticos que a los humanistas. Sin embargo, las fechas pueden ser subjetivamente muy relevantes para los historiadores, cuando traen a la mente casi espontáneamente sucesos que ayudaron a cambiar el devenir de los tiempos. Y en el primer tercio del siglo XIII algunas fechas son clave en la modificación social del noroeste hispano. Así, el año 1230, recordado por todos por la desaparición del Reino de León, es una fecha muy señalada en el plano sociopolítico. Los años y 1212 y 1218 son momentos importantes en el ámbito sociocultural, porque en ellos se produjo respectivamente la fundación de las Universidades de Palencia y Salamanca. Y el año 1215 es esencial en el terrero socioreligioso para el lejano noroeste hispano, porque, como se ha visto, el devenir de la Iglesia y en parte de toda la sociedad tomó un nuevo rumbo, como en este artículo hemos pretendido manifestar.

\section{FUENTES}

Alberigo, J. 1962. Conciliorum Oecomenicorum Decreta: 203-247. Freiburg: Herder.

Cirot, G. 1912. «Chronique latine inédite des Rois de Castille jusqu'en 1236». Bulletin Hispanique 14/2: 353-374.

Domínguez Sánchez, S. 1996. Documentos de Clemente IV (1265-1268) referentes a España. León: Ed. de la Univ. de León.

Domínguez Sánchez, S. 1997. Documentos de Gregorio X (1272-1276) referentes a España. León: Ed. de la Univ. de León.

Domínguez Sánchez, S. 2004. Documentos de Gregorio IX (1227-1241) referentes a España. León: Ed. de la Univ. de León.

Domínguez Sánchez, S. 2009. Documentos de Nicolás IV (1288-12982) referentes a España. León: Ed. de la Univ. de León.

Domínguez Sánchez, S. 2015. Documentos de Honorio IV (1285-1287) referentes a España. León: Ed. de la Univ. de León.

Erdmann, C. 1927. Papsturkunden in Portugal. Berlín: Vandenhoeck \& Ruprecht.

Fernández Valverde, J. (ed.) 1987. R. Ximénez de Rada, Historia de Rebus Hispanie sive Historia Gothica. Turnhout: Brepols.

Flórez, E. 1748. España Sagrada. III. Contiene la predicación de los apóstoles en España; propagación de la Cristiandad desde el siglo primero; origen, progreso y mutación de la Misa antigua en estos reinos. Madrid: Portería de San Phelipe el Real; ed. de R. Lazcano 2002. Madrid: Editorial Revista Agustiniana.

Flórez, E. 1751. España Sagrada. VI. Trata de la Santa Iglesia de Toledo en cuanto metropolitana; de sus concilios y honores sobre las demás iglesia de estos reinos; juntamente con los santos de la diócesis y provincia antigua de Toledo. Madrid: Impr. de Antonio Marín; 3a ed. 1859. Madrid: Impr. de José Rodríguez.

Flórez, E. 1765. España Sagrada. XX. Historia Compostelana. Madrid: Imprenta de la viuda de Eliseo Sánchez; reimpr. 1965. Madrid: Real Academia de la Historia.
García y García, A. 1981. Constitutiones Concilii quarti Lateranensis, una cum Commentariis glossatorum. Ciudad del Vaticano: Monumenta Iuris Canonici. Series A: Corpus glossatorum 2.

González Balasch, M. ․ T. 2004. Tumbo B de la catedral de Santiago. Estudio y edición. Santiago de Compostela: Publ. de la Catedral de Santiago de Compostela.

Hernández, F. J. 1996. Los cartularios de Toledo. Catálogo documental: 531, núm. 648. Madrid: Fundación Ramón Areces.

Jaffé, Ph. 1851. Regesta Pontificum Romanorum, ab condita Ecclesia ad annum post Christum natum MCXCVIII. Leipzig: Veit et Comp.; 2a ed. de S. Loewenfeld, F. Kaltenbrunner y P. Ewald. 1885-1888, 2 v., Leipzig: Veit et Comp.

Loaysa y Girón, G. de. 1595. Collectio conciliorum Hispaniae. Madrid: Impr. de P. Madrigal.

Mansi, G. D. 1778. Sacrorum Conciliorum nova et amplissima collectio, t. XXII, Venecia: Impr. de Antonio Zatta.

Mansilla Reoyo, D. 1955. La documentación pontificia hasta Inocencio III. Roma: Instituto Español de Estudios Eclesiásticos.

Mansilla Reoyo, D. 1965. La documentación pontificia de Honorio III (1216-1227). Roma: Iglesia Nacional Española.

Martène, E. y Durand, U. 1717. Thesaurus novus anecdotarum seu collectio monumentorum complectens regnum ac principum aliorumque virorum illustrium epistulas et diplomata bene multa: IV. París: Fl. Delaulne.

Pressutti, P. 1888. Regesta Honorii Pape III, 2 v. Roma: Typographia Vaticana; reed. 1978. Hildesheim-New York: Georg Omes Verlag.

Quintana Prieto. A. 1987. La documentación pontificia de Inocencio IV, 2 v.. Roma: Iglesia Nacional Española.

Sánchez Sánchez, X. M. 2009. Catálogo de manuscritos do arquivo-biblioteca da catedral de Santiago de Compostela. Santiago de Compostela: Consello da Cultura Galega. Fontes para a Historia de Galicia.

\section{BiBLIOGRAFÍA}

Aldea Vaquero, Q.; Marín Martínez, T. y J. Vives Gatell (eds.) 1973. Diccionario de Historia Eclesiástica de España, III. Madrid: Instituto Enrique Flórez del CSIC.

Alfonso Antón, I., Kennedy, H.N. y Escalona Monge, J. (eds.) 2003. Building legitimacy. Political Discourses and Forms of Legitimation in Medieval Societies, II. Leiden-Boston: Brill, The Medieval Mediterranean.

Azais, Y., Thouzellier, C. y Fliche, A. 1975. «El cuarto Concilio de Letrán» en A. Fliche y V. Martin (eds.), La Cristiandad Romana, X: 201-219, ed. Española. Valencia: Edicep.

Branco, M. a J. 2011. "Constructing Legitimacy and Using Authority. The Production of Cartularies in Braga during the $12^{\text {th }}$ Century", en K. Herbers e I. Fleisch (eds.), Erinnerung - Niederschrift Nutzung. Das Papsttum und die Schriftlichkeit im mittelalterlichen Westeuropa: 31-62, Berlín/Nueva York: De Gruyter.

Castejón y Fonseca, D. 1645. La primacía de la iglesia de Toledo. Madrid: Impr. de Diego Díaz de la Carrera.

Cavero Domínguez, G. 2015. "Pedro Muñiz, obispo de León (12051206) y arzobispo compostelano (1207-1224)», en: R. Córdoba de la Llave, J.L. del Pino García y M. Cabrera Sánchez. Estudios en homenaje al profesor Emilio Cabrera: 111-122. Córdoba: Ed. Univ. de Córdoba y Univ. de Extremadura.

Cunha, M.a C. 2013. "Coimbra and Porto: Episcopacy and Nacional Identity in Diocesan Border Quarrels»: K. Herbers, F. López Alsina y F. Engel (eds.), Das Begrenzte Papsttum. Spielräume Päpstlichen Handelns. Legaten- Delegierte Richter- Grenzen: 133-145. Berlín/ Boston: De Gruyter.

Domínguez Sánchez, S. y Herbers, K. (coords.) 2009. Roma y la Península Ibérica en la Alta Edad Media. La construcción de espacios, normas y redes de relación / Rom und die Iberische Halbinsel im Hochmittelalter. Die Konstruktion von Räumen, Normen und Netzwerken. León-Göttingen: Eds. Universidad de León.

Duchesne, L. 1900. "Saint Jacques en Galice». Annales du Midi 12: 154-179. 
Falque Rey, E. 1994. Historia Compostelana. Introducción, traducción, notas e índices: 7-10, Madrid: Akal.

Feige, P. 1978. «Die Anfänge des portugiesischen Königtums und seiner Landeskirche». Gesammelte Aufsätze zur Kulturgeschichte Spaniens 29: 405-406.

Feige, P. 1988. «Zum Primat der Erzbischöfe von Toledo über Spanien. Das Argument seines westgotischen Ursprungs im toledaner Primatsbuch von 1253»: Fälschungen im Mittelalter. Internationaler Kongress der Monumenta Germaniae Historica: 675-714. Hannover: Hahnsche Buchhandlung.

Feige, P. 1991. "La primacía de Toledo y la libertad de las demás metrópolis de España. El ejemplo de Braga», en La introducción del Císter en España y Portugal: 72-74. Burgos: La Olmeda.

Fita Colomé, F. 1902. "Santiago de Galicia. Nuevas impugnaciones y nuevas defensas». Razón y Fe I/2: 35-45 y 178-195.

Fleisch, I. 2011. «Rechtsstreit und Schrifkultur - Zum Vordringen des römisch-kanonischen Prozessrechts aud der Iberischen Halbinsel», en K. Herbers e I. Fleisch (eds.), Erinnerung - Niederschrift Nutzung. Das Papsttum und die Schriftlichkeit im mittelalterlichen Westeuropa: 93-118, Berlín/Nueva York: De Gruyter.

Fuente, V. de La. 1873-1875. Historia eclesiástica de España. Madrid: Compañía de Impresores y Libreros del Reino; ed. de 1973. Madrid: Biblioteca de Autores Cristianos.

García y García, A. 1958. «El Concilio de Letrán y sus comentarios». Traditio 14: 484-502.

García y García, A. 1959. «Los comentarios de los canonistas a las constituciones del Concilio IV de Letrán». Bibliothèque de la Revue d'Histoire Ecclésiastique 33: 151-161.

García y García, A. 1972. "Concilio de Letrán IV» en Q. Aldea Vaquero, T. Marín Martínez y J. Vives Gatell (eds.), Diccionario de Historia Eclesiástica de España, I: 477-478. Madrid: Instituto Enrique Flórez del CSIC.

García y García, A. 1987, «El Concilio IV Lateranense y la Península Ibérica», en A. García y García (ed.), Iglesia, Sociedad y Derecho, II: 204-208. Salamanca: Ed. de la Universidad Pontificia.

García Villoslada, R. 1953. Historia de la Iglesia católica. II. Edad Media. II. Madrid: Biblioteca de Autores Cristianos.

Gibbs, M. y Lang, L. 1962. Bishops and reform, 1215-1272. With special reference to the Lateran council of 1215, 2a ed. Londres: Oxford University Press.

González, J. 1944. Alfonso IX: II. Madrid: Instituto Jesónimo Zurita del CSIC.

González Vázquez, M. 1996. El arzobispo de Santiago: una instancia de poder en la Edad Media (1150-1400). Sada (La Coruña): Ed. do Castro.

Gorosterratzu Jaunarena, J. J. 1925. Don Rodrigo Jiménez de Rada, gran estadista, escritor y prelado. Estudio documentado de su vida, de los cuarenta años de su primacía en la Iglesia de España y de su cancillerato de Castilla; y en particular, la prueba de su asistencia al Concilio IV de Letrán, tan debatida en la controversia de la venida de Santiago a España: 177. Pamplona: Impr. y Lib. de viuda de T. Bescansa.

Hefele y Leclercq, J. 1913. Histoire des Conciles, V/2. Paris: Librairie Letouzey et Ané.

Henriet, P. 2004. «Political Struggle and the Legitimation of the Toledan Primacy: The Pars Lateranii Concilii», en I. Alfonso Antón, H. N. Kennedy y J. Escalona Monge (eds.), Building legitimacy. Political Discourses and Forms of Legitimation in Medieval Societies, II: 291318. Leiden-Boston: Brill, The Medieval Mediterranean.

Herbers, K. 1994. "Politik und Heiligenverehrung aut der iberischen Halbinsel», en J. Petersohn (ed.). Politik und Heiligenverehrung im Hochmittelalter: 177-275 Sigmaringen: Jan Thorbecke Verlag.

Herbers, K. 2006. Política y veneración de santos en la Península Ibérica. Desarrollo del "Santiago político». Pontevedra: Fundación Cultural Rutas del Románico.

Horn, M. 1991. «Der Streit um die primatswürde der Erzbischöfe von Toledo. Ein beitrag zur Geschichte der älteren Papstregister». Archivum Historiae Pontificiae 29: 259-280.

Kuttner, St. y García y García, A. 1964. «A new Eyewitness Acount on the Fourth Lateran Council». Traditio 20: 115-178.
Linehan, P. 1975. La Iglesia española y el Papado en el siglo XIII. Salamanca: Ediciones de la Universidad Pontificia.

Linehan, P. A. 1988. «The Toledo forgeries, c. 150-1300», in Fälschungen in Mittelalter. Internationaler Kongress der Monumenta Germaniae Historica: 646-674. Hannover: Hahnsche Buchhandlung.

Lomax, D. W. 1969. "The Lateran Reforms and Spanish Literature»: Ibero-Romania 1: 299-313.

López Alsina, F. 2011, "Los Tumbos de Santiago de Compostela y las relaciones con el Pontificado», en K. Herbers e I. Fleisch (eds.), Erinnerung - Niederschrift - Nutzung. Das Papsttum und die Schriftlichkeit im mittelalterlichen Westeuropa: 137-170, Berlín/ Nueva York: De Gruyter.

López Alsina, F. 2013 «El 'Parrochiale Suevum’ y su presencia en las cartas pontificias del siglo XII», en K. Herbers, F. López Alsina y F. Engel (eds.), Das Begrenzte Papsttum. Spielräume Päpstlichen Handelns. Legaten- Delegierte Richter- Grenzen: 105-131. Berlín/ Boston: De Gruyter.

López Ferreiro, A. 1898-1911. Historia de la santa apostólica metropolitana iglesia de Santiago de Compostela, 11 vols., Santiago de Compostela: Imprenta del Seminario Conciliar Central; reimpr. 1983. Santiago de Compostela: Sálvora.

Luchaire, A. 1905. «Un document retrouvé». Journal des Savants 3: 557-568.

Luchaire, A. 1908. Innocent III. Le Concile de Latran et la Réforme de I'Église, París: Libraire Hachette et Cie.

Mansilla Reoyo, D. 1961. «Formación de la provincia bracarense después de la invasión árabe». Hispania Sacra 14: 5-25.

Mansilla Reoyo, D. 1972. "Geografía eclesiástica», en Q. Aldea Vaquero, T. Marín Martínez y J. Vives Gatell (eds.), Diccionario de Historia Eclesiástica de España, II: 983-1015. Madrid: Instituto Enrique Flórez del CSIC.

Mansilla Reoyo, D. 1994. Geografía eclesiástica de España: estudio histórico-geográfico de las diócesis, 2 v., Madrid: Iglesia Nacional Española de Roma.

Martín Martín, J. L. 2011. «Transmisión y eficacia de la documentación pontificia medieval en las diócesis de la Extremadura castellanoleonesa», en K. Herbers e

I. Fleisch (eds.), Erinnerung - Niederschrift - Nutzung. Das Papsttum und die Schriftlichkeit im mittelalterlichen Westeuropa: 171-194, Berlín/Nueva York: De Gruyter.

Pérez Rodríguez, F. J. 1994 El dominio del cabildo catedral de Santiago de Compostela en la Edad Media (siglos XII-XIV). La Coruña: Ed. Tórculo.

Pyck, L. K. 2004. Conflict ac Coexistence: Archbishop Rodrigo and the Muslims and Jews of Medieval Spain. Michigan: University of Michigan Press.

Rivera Recio, J. F. 1951 «Personajes hispanos asistentes en 1215 al IV Concilio de Letrán». Hispania Sacra 4: 335-355.

Rivera Recio, J. F. 1966. La Iglesia de Toledo en el siglo XII (1086-1208): esp. pp. 315-389. Roma: Iglesia Nacional Española.

Rivera Recio, J. F. 1973. «Primado de Toledo o Primado de las Españas», en Q. Aldea Vaquero, T. Marín Martínez y J. Vives Gatell (eds.), Diccionario de Historia Eclesiástica de España, III: 2024-2027. Madrid: Instituto Enrique Flórez del CSIC.

Schieffer, R. 2013. «Die Reichweite päpstlicher Entscheidungen nach der papstgeschichtlichen Wende», en K. Herbers, F. López Alsina y F. Engel (eds.), Das Begrenzte Papsttum. Spielräume Päpstlichen Handelns. Legaten- Delegierte Richter- Grenzen: 13-27. Berlín/ Boston: De Gruyter.

Sucona i Vallès, T. 1899, El primado tarraconense, Tarragona: Impr. de F. Arís e Hijo.

Vones Liebenstein, U. 2013. «Narbona metropolis: Grenzen zwischen kirchlichen Interessen und weltlicher Herrschafsbildung», en K. Herbers, F. López Alsina y F. Engel (eds.), Das Begrenzte Papsttum. Spielräume Päpstlichen Handelns. Legaten- Delegierte RichterGrenzen: 147-167. Berlín/Boston: De Gruyter.

Weiß, S 1995. Die Urkunden der päpstlichen Legaten von Leo IX. bis Coelestin III. (1049-1198): 173-203. Colonia-Weimar-Viena: Böhlau. 